\title{
EFEITO DAS ÉPOCAS DE CALAGEM NA DISPONIBILIDADE DE FÓSFORO APLICADO 180 DIAS ANTES DO PLANTIO DO ARROZ (Oryza sativa, L.) EM LATOSSOLOS SOB CERRADO
}

JOSÉ RAFAEL MÉNDEZ BALDEÓN

Orientador: Prof. Dr. TOSHIAKI KINJO

Dissertação apresentada à Escola Superior de Agricultura "Luiz de Queiroz", da Universidade de São Paulo, para obtenção do título de Mestre em Agronomia. Área de Concentração: Solos e Nutrição de Plantas.

PIRACICABA

Estado de São Paulo - Brasil

Dezembro = 1986 
A minha esposa,

Maria dos Anjos,

DEDICO .

A meus pais, irmãos e

demais membros da familia,

OFEREÇO . 


\section{AGRADECIMENTOS}

A Fundação de Amparo à Pesquisa do Estado de São Paulo (FAPESP) e ao Conselho Nacional de Desenvolvimento Cientifico e Tecnolögico (CNPq), pelo financiamento do Cur so de Pós-Graduação; à Escola Superior de Agricultura "Luiz de Queiroz" (ESALQ-USP), pelos ensinamentos e facilidades oferecidas.

Ao Instituto Equatoriano de Crëdito Educativo y Be cas (IECE), pela oportunidade e emprēstimo outorgado, para realizar o curso de Mestrado em Solos e Nutrição de Plantas.

Ao Professor Orientador, Dr. Toshiaki Kinjo, pela orientação na realização do presente trabalho, pela sua dedicação. constante em transmitir seu conhecimento, pelo apoio seguro e espontâneo e, ainda, pela amizade com que sempre me distinguiu.

Aos Professores do Departamento de Solos, Geologia e Fertilizantes, pela assiduidade e empenho no cumprimento da missão de ensinar; aos membros da Banca Examinado ra, pelas sugestões e criticas ao trabalho; Dr.Roberto A. Arévalo, pela sua amizade, apoio moral e presteza dispensada durante todo o período de realização do curso; Dr. Mo rel P. Barbosa Filho, pesquisador do Centro Nacional de Pesquisa de Arroz e Feijão (CNPAF), pela colaboração e apoio dispensado durante a etapa experimental e de labora törio da presente pesquisa. 
Aos Senhores Fausto Espin Garcia e Washington Velez, amigos de Guayaquil - Ecuador, pela presteza dispensada e que espontaneamente me incentivaram na realização do curso e resolução de meus interesses particulares.

Ao pessoal do Laboratório do Departamento de Solos, Geologia e Fertilizantes, nas pessoas de Mário Ludovico e de Vanda Maria Zancheta e aos demais funcionários desse Departamento, pela colaboração nas anälises de laboratório.

Aos Senhores Francisco de Assis Portela e Dorival Grisotto, pelo valioso auxilio nos trabalhos experimentais. A Senhora Tekla Eunice Klar, pela gentileza dispensada em todo momento, pelos serviços constantes de datilografia e pela amizade proporcionada.

Aos companheiros e amigos Adolfo Sanchez Coelho e Juan Carlos Quevedo Camacho, pela amizade, pelo apoio e pelo incentivo dispensado durante todo o periodo de realiza ção do curso, aos demais colegas e amigos pela amizade e convivio estudantil e que de alguma maneira contribuiram pa ra a realização deste trabalho.

Finalmente, à minha querida esposa Maria dos Anjos, à minha mãe Zoila Baldeón de Mēndez, que alēm do carinho, incentivo e compreensão, colaboraram tambēm para o êxito alcançado no curso.

O Autor agradece penhoradamente. 
RESUMO $\ldots \ldots \ldots \ldots \ldots \ldots \ldots \ldots \ldots \ldots \ldots \ldots \ldots$

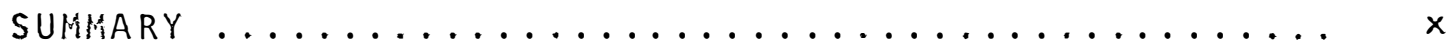

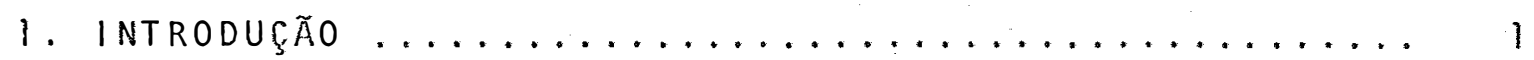

2. REVISÃO DE LITERATURA ..................

2.1 .0 fösforo no solo .................. 4

2.2. Reações de fertilizantes fosfatados em solos... 6

2.3. Fatores que afetam a eficiência dos fertilizantes fosfatados ...................... 11

2.3.1. Fatores inerentes ao fosfato ........ 11

2.3.2. Fatores inerentes ao solo ............ 15

2.3.3. Fatores inerentes à planta ......... 16

2.4. Resultados experimentais obtidos com fosfatos naturais parcialmente solubilizados.......... 17

2.5. Fracionamento de fósforo e fösforo disponível

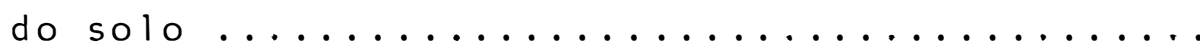

3. MATERIAL E METODOS ........................... 30

3.1. Características dos solos e fosfatos usados nos experimentos ......................... 30

3.2. Delineamento experimental ............. 33

3.3. Instalação e condução dos experimentos em casa

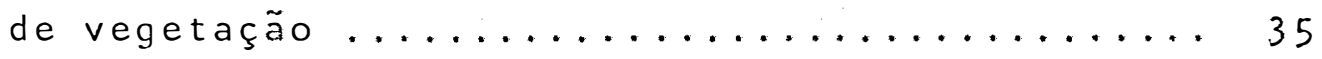




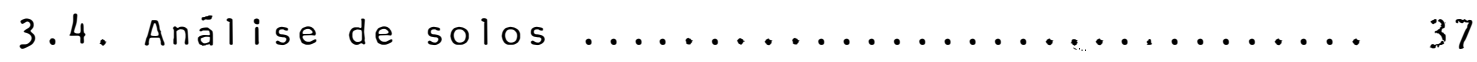

3.4.1. Mētodos de extração de fösforo......... 38

3.4.1.1. Mëtodo de 01 sen +EDTA ....... 38

3.4.1.2. Métado de Mehlich ............3 38

3.4.1.3. Método de Resina ............38

3.4.1.4. Método de Bray-1 ...........39

3.4.2. Fracionamento do fösforo ........... 40

3.5. Anälise do material vegetal ............. 40

3.6. Anälises estatísticas ..................... 41

4. RESUltadoS E DISCUSST̃O ..................... 42

4.1. Formas de fosfatos inorgänicos ........... 42

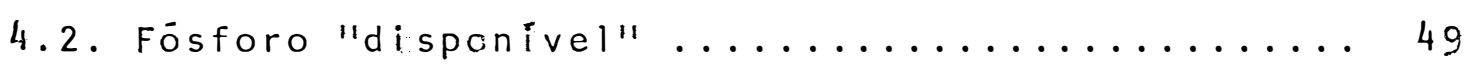

4.3. Relações entre fösforo "disponivel" e frações inorgânicas de fösforo ..................60 60

4.4. Resposta do arroz aos fatores estudados.......65

4.5. Relação entre teores de fósforo no solo e resposta do arroz .......................... 71

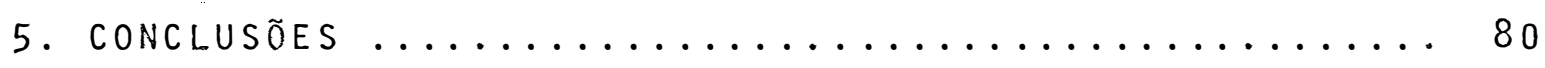

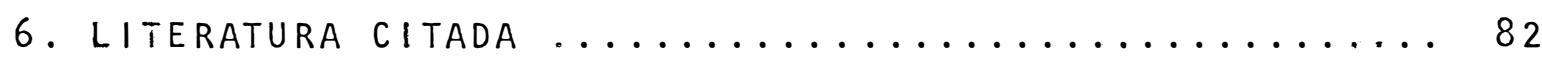


EFEITO DAS EPOCAS DE CALAGEM NA DISPONIBILIDADE DE FÓSFORO

APLICADO 180 DIAS ANTES DO PLANTIO DO ARROZ

(Oryza sativa, L.) EM LATOSSOLOS SOB CERRADO

Autor: JOSE RAFAEL MENDEZ BALDEON

Orientador: PROF. DR. TOSHIAKI KINJO

\section{RESUMO}

Foi conduzido um experimento em casa-de-vege tação, com superfosfato triplo (SPT) e Fosfato de Araxä Par cialmente Solubilizado (FAPS), em dois Latossolos com os objetivos de: (a) avaliar a eficiência da aplicação prévia do FAPS e do SPT, em relação às diferentes épocas de calagem, so bre o rendimento de matēria seca e fósforo absorvido pelo arroz de sequeiro em solos sob cerrado; (b) investigar a mudança na disponibilidade de fōsforo, nas diferentes ëpocas de aplicação do calcärio, considerando o tempo de reação entre calcärio e fosfato e (c) estudar as relações entre as frações de fosfatos inorgânicos e os teores de fósforo "disponível" obtidos em diferentes extratores.

Amostras de dois solos, Latossolo Vermelho Amarelo distrōfico (LVd) e Latossolo Vermelho Escurodistrófí co (LEd), foram incubados com 150 ppm de P, nas formas de FAPS e de SPT, por um período de 180 dias. A cada 90 dias o 
calcário foi aplicado, obtendo-se três períodos de incubação entre calcário e fosfatos, em dias: 180,90 e 0 . Ao fim do periodo de incubação procedeu-se a amostragem de solo para anālise. Em seguida, transferem-se $3,0 \mathrm{~kg}$ de terra para vasos de barro e fez-se o plantio do arroz, cultivar IAC-165.

Os tratamentos consistiram de combinações de dois solos, dois fosfatos e quatro periodos de incubação. 0 fracionamento de $P$ do solo, P "disponivel" em quatro extratores (Mehlich, 01 sen + EDTA, Bray-l e Resina) e a produção de matēria seca e fósforo absorvido foram utilizados como parâmetros de avaliação.

Quando os adubos fosfatados são aplicados em solos sob cerrado 180 dias antes do plantio do arroz, a produção de matēria seca da parte aérea aumenta com o tempo de reação do calcário no solo que recebe o SPT e a quantidade de fösforo absorvido tende a acompanhar a tendência da produção de matēria seca. Com a adição do FAPS a produção de matéria seca tende a diminuir na medida que aumenta o tempo de reação entre calcário e adubo, a quantidade de fósforo absorvido neste caso não acompanha a produção de matèria seca.

Com o emprego de SPT em ambos os solos, os teores de fósforo "disponível" extraidos pelos extratores Meh lich, Bray-l e Resina, não variam significativamente com os tempos de reação do calcário e adubo; mas no caso do extrator $0 l$ sen + EDTA, os teores de P "disponivel" no LVd aumentarão 
com os tempos de reação do calcārio e SPT. Quando se adiciona o FAPS no LVd, os teores de fósforo extraído pelos extratores Mehlich e 0lsen + EDTA, tendem a diminuir na medida que aumentam os tempos de reação entre calcärio e FAPS.

Na ausência de calcário em ambos os solos,os teores de fósforo extraídos por Bray-l e Mehlich tendem a diminuir com o emprego de SPT e aumentar com FAPS, em compara ção aos tratamentos com calcário.

Os teores de fösforo "disponivel" determina dos pelos extratores Mehlich e Bray-l estão correlacionados positivamente com os de $\mathrm{P}-\mathrm{NH}_{4} \mathrm{Cl}$, P-Fe e P-Ca e essas relações tambēm acompanham a produção de matēria seca e fósforo absorvido na parte aérea do arroz. 


\section{EFFECT OF THE LIMING TIME ON PHOSPHORUS AVAILABILITY APPLIED \\ 180 DAYS PRIOR TO THE SEEDING OF RICE (oryza sativa,L.) \\ EM LATOSSOLOS SOB CERRADO}

Author: JOSE RAFAEL MENDEZ BALDEON

Adviser: Prof. Dr. TOSHIAKI KINJO

\section{SUMMAPY}

An experiment was carried out in green-house, with triple superphosphate (TSP) and partialy solubilized Araxá rock phosphate (PSARP), in two latosols with the following objectives: (a) to evaluate the efficiency of the previous application of PSARP and TSP in relation to different liming time on the dry matter yield and phosphorus absorption by uplant rice crop in soils under cerrado vegetation; (b) to. investigate the change on phosphorus availability, in different times of lime application, considering the reaction time of lime with phosphate, and (c) to study the relations between fractions of inorganic phosphate and the content of "available" phosphorus obtained in different extractants.

Samples of two soils, Red Yellow Latosol (LVd) and Dark Red Latosol (LEd), were incubate with 150 ppm of P, in the forms of PSARP and TSP, during a period of 180 days. Every 90 days the lime was applied and it was obtained three 
reaction time of 1 ime with phosphate: 180,90 and 0 days. At the end of incubation period soil samples were separated for analysis. And $3.0 \mathrm{~kg}$ of soil were transfered to the ceramic pots and rice, IAC-165 cultivar, were sown.

The treatments consisted of combinations of two soils, two phosphates and four incubation time. The soil P fractionation, "available" P determined by four extractants (Mehlich, 0lsen + EDTA, Bray-l and Resin). The dry matter yield and the absorved $P$ were utilized as the evaluating parameters.

When the phosphate fertilizers are applied in soils under Cerrado vegetation 180 days prior to the seeding of rice, the dry matter yield of above ground part increases with the reaction time of lime in the soil, which receive TSP, and the quantity of absorved phosphorus tend to accompany the tendency of dry matter yield. With the addition of PSARP, the dry matter yield tends to decrease with increasing reaction time of lime with PSARP. The quantity of absorved phosphorus in this case, doesn't accompany the dry matter yield.

Using TSP em both soils, the contents of extracted "available" phosphorus by Mehlich, Bray-l and Resin extractants, don't vary significantly with the reaction times of lime with fertilizer. But in the case of the 0lsen + EDTA extractant, the contents of "available" phosphorus in LVd 
increase with reaction time of 1 ime and TSP. Using PSARP in LVd the contents of extracted $P$ by Mehlich and 0lsen + EDTA extractants, tend to decrease with the increase of reaction time of lime with PSARP.

Without lime application in both soils, the contents of extracted $P$ by Bray-l and Mehlich, tend to decrease with TSP and to increase with PSARP, in relation to the treatments which received lime.

The contents of "available" $P$ determined by Mehlich and Bray-l extractants are correlationed positively with $\mathrm{P}-\mathrm{NH}_{4} \mathrm{Cl}, \quad \mathrm{P}-\mathrm{Fe}$ and $\mathrm{P}-\mathrm{Ca}$ and these relations also accompany the dry matter yield and $P$ absorved in the above ground part of rice. 


\section{InTRODU̧ÃO}

o fösforo è .um dos macronutrientes essenpara a vida das plantas, que com mais freqüéncia e intens dade limita a produção nas regiões subtropicais e tropicais e por isso o mais fornecido como adubo. Por ser sua deficiência nos solos bastante generalizada para todas as culturas, a caracterização deste elemento no solo e a quan tificação de sua disponibilidade efetiva para as plantas, há muito têm preocupado os especialistas em fertilidade do solo.

A correção da deficiência de fósforo se faz normalmente, pela aplicação de fosfatos altamente solüveis, como os superfosfatos simples e tripio, de elevado custo para o produtor. Estes fertilizantes ao se dissolverem em ägua, transformam-se em àcido fosförico e fosfatos àcidos de cālcio. Essa solução àcida que se forma no local de aplicação do fertilizante, exerce um efeito marcante na disponibilidade de fósforo para as plantas, uma vez que - $\mathrm{H}_{3} \mathrm{PO}_{4}$ produzido concorre para a dissolução dos öxidos de Fe, 
Al e Mn, acelerando o processo de fixação de fósforo, sobretudo, em solos de cerrado (LINDSAY et alii, 1962).

Devido às dificuldades encontradas pelas indūstrias de fertilizantes no Brasil para a obtenção de àcidos sulfūrico, necessário para a obtenção de superfosfa tos, torna-se de extrema importância investigar a possível substituição desses fosfatos por fontes naturais finamente moidas ou parcialmente processadas. Os fosfatos parcialmen te acidulados reagem bem em solos àcidos e deficientes em fósforo, apresentando uma eficiência muito próxima a dos fosfatos monocálcicos, quanto aos seus efeitos sobre o solo e a planta, conforme demonstram os estudos realizados por FERREIRA e KAMINSKI (1979), MALAVOLTA et alie (1981), NAKAYAMA (1982), FREIRE et alie (1983), BARBOSA FILHO et alii (1983). Entretanto, os resultados destes não são definitivos quanto a sua real aplicação agronômica, sendo, portanto, necessários maiores estudos para respon der a muitas indagações notadamente sobre o efeito do tempo de contato dos fosfatos naturais parcialmente acidula dos com o solo e sua eficiência na presença e ausência de calagem. Estas questões ainda permanecem sem resposta, conquanto, jä as conhecem para os fosfatos naturais aplicados em diferentes solos.

Acredita-se que fosfatos parcialmente acidu lados estão constituídos por uma fração insolüvel (fosfato tricāicico) e outra solūvel (fosfato monocālcico); e que 
esta ūltima fração formaria ācido fosfórico que abaixaria o pH do meio, favorecendo dessa maneira a solubilização do fosfato natural remanescente e ao mesmo tempo a formação de fosfatos insolūveis de Fe e Al, porém, a aplicação do calcário elevaria o pH do solo e consequentemente a solubi lidade destes compostos de fósforo. Em razão disso, se ate nuaria o problema de fixação de fósforo, aumentando a eficiência deste tipo de adubo e a liberação de fósforo para as plantas. Partindo-se desta hipótese, o uso de fosfatos parcialmente acidulados, poderia ser mais promissor sobre tudo em solos que apresentam caracteristicas de solo de cerrado.

Este trabalho teve os seguintes objetivos: a) avaliar sob casa de vegetação, a eficiência da aplicação prévia do fosfato Araxă parcialmente solubilizado (FAPS) e do superfosfato triplo (SPT), em relação às diferentes épocas de calagem, sobre o rendimento de matéria seca e fósforo absorvido pelo arroz de sequeiro (oryza sativa L.) em solos sob cerrado (b) investigar a mudança na disponibilidade de fósforo, nas diferentes épocas de aplicação de calcärio, considerando o tempo de reação entre calcārio e fosfato;c) estudar as relações entre os teores de formas inorgânicas do fósforo e os teores de fósforo "disponivel" obtidos em diferentes extratores. 


\title{
2. REVISÃo dE LITERATURA
}

\section{1. o fósforo no solo}

\begin{abstract}
No solo o fósforo ocorre quase exclusiva*mente como ortofosfato em concentrações da ordem de 0,02 a 0,15\% (MENGEL e KIRKBY, 1979). Basicamente o fósforo encontra-se no solo associado à matēria orgânica e fazendo parte de compostos inorgânicos bastante insolúveis. A proporção dessas duas formas é muito variävel, podendo o fósforo or gânico representar mais da metade do teor total na camada arāiel (CABALA e FASSBENDER, 1970). o p orgânico, embora não esteja relacionado com sua disponibilidade para as plantas, pode ser importante para a nutrição das plantas cultivadas em solos tropicais recém desmatados, devido à rāpida decomposição de matēria orgânica. As formas inorgâni cas de fósforo são, em geral, as que representam interesse direto para a nutrição das plantas, podendo ser agrupadas nas formas de fosfato de alumínio (P-Al), fosfato de ferro
\end{abstract}


$(P-F e)$, fosfato de cälcio $(P-C a)$, fosfatós oclusos de ferro e alumínio e o P-solüvel em àgua.

As formas inorgânicas de $P$ mais conhecidas em solos äcidos são as de $P$ ligado a Fe e Al, representạ dos pela estrengita e variscita, respectivamente. A tran formação de uma forma de fosfato em outra è controlada principalmente pelo pH do solo. Assim que os solos tornam se mais àcidos, a atividade do Fe e Al aumenta e as formas mais solüveis de $\mathrm{P}-\mathrm{Ca}$ são convertidas para $\mathrm{P}-\mathrm{Al}$ e $\mathrm{P}-\mathrm{Fe}$ (CHANG e JACKSON, 1958). A separação dessas formas, conhe-cida ; como fracionamento de fösforo por CHANG e JACKSON (1957), tem sido importante em solos tropicais, quando cor relacionadas com os teores de fósforo disponivel, conforme ressaltam os trabalhos de BIASI (1978); TANAKA et ali (1981) e BAHIA FILHO et alii (1982).

Do ponto de vista nutricional podem ser re conhecidas em solos três frações de fösforo muito importan tes, no estudo da disponibilidade desse nutriente, confor me mostra o esquema geral abaixo, de fornecimento de fósfo ro às plantas (MALAVOLTA, 1976).

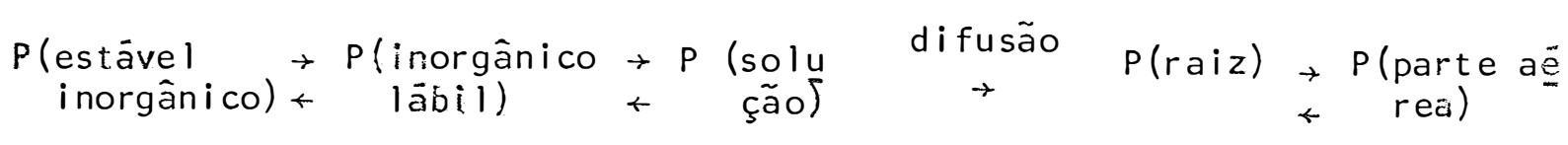

$$
\begin{aligned}
& \text { (fator quan- (fator in. } \\
& \text { tidade) tensidade) }
\end{aligned}
$$

\footnotetext{
o P-solução, representa o fösforo dissolvido na fase liquida do solo normalmente encontrado em
} 
concentrações muito baixas, da ordem de 0,1 - 1 ppm (LARSEN, 1967). As plantas absorvem fósforo da solução que movimenta até a superfície daśraízes por difusão, devido ao gradiente de concentração de íons fosfato na solução.

Dái, a importância da manutenção de um nível adequado de fósforo na solução do solo. os teores de fósforo em solu ção é bastante variāvel em função principalmente da textura e da espécie vegetal. Segundo SMYTH e SANCHEz (1980), o nivel de fósforo considerado como critico para a cultura do arroz de sequeiro, cultivado em solos sob cerrado de Pla naltina (DF), situa-se entre 2,0 e 5,0 ppm de $P$.

Uma parte do fósforo da fase sōlida, denominada por. LARSEN (1967), de p-lábil, mantém em equilíbrio rápido com o fósforo da solução do solo. O restante do fós foro insolūvel:da fase sōlida denominado p-não lábil pode ser liberado muito lentamente e entrar em equilibrio com o fósforo do reservatório lábil (MENGEL e KIRKBY, 1979) e em função do tempo entrar em equilibrio com o fósforo da solução.

\subsection{Reaçöes de fertilizantes fosfatados em solos}

os ions fosfatos liberados pela dissolução de fertilizantes, adicionados como adubos, não permanecem estáveis no solo, passando a formas menos solüveis através de sua reação com os minerais do solo. Em solos áci 
dos, este fenômeno assume grande importância, já que grande parte dos fertilizantes aplicados reagem com os óxidos hidratados de Fe e Al, existentes em grandes quantidades nos solos, reduzindo, a teores minimos, o fósforo disponivel para as plantas.

Dois tipos de reações que causam a retenção dos íons fosfäto foram apresentados por ColEman et alii (1960); LINDSAY et alii (1962); HSU (1965) e PARFITT et alii (1975). A primeira é a precipitação de fosfatos de baixa solubilização do tipo $\mathrm{FePO}_{4} \cdot 2 \mathrm{H}_{2} \mathrm{O}, \mathrm{AlPO}_{4} \cdot 2 \mathrm{H}_{2} \mathrm{O}$ e outros compostos cristalizados ou amorfos que se formam como resultado da reação do fosfato monocálcio com $\mathrm{Fe}$ e Al existentes na solução do solo, conforme a reação (1) sumarizada abaixo:

$$
\left[\mathrm{Al}_{6}(\mathrm{OH})_{12}\right]^{+6}+6 \mathrm{H}_{2} \mathrm{PO}_{4}^{-} \rightarrow \mathrm{Al}_{6}(\mathrm{OH})_{12}\left(\mathrm{H}_{2} \mathrm{PO}_{4}\right)_{6}
$$

A segunda reação representa a adsorção, em que o fosfato entra em coordenação com os ions Fe e Al nas superficies das argilas e dos óxidos, assin como ocorre nas reações de troca de ligante. A adsorção pode ser representada pela equação (2) como segue:

$$
\mathrm{Al}_{\mathrm{Al}-\mathrm{OH}}^{+\mathrm{OH}}+\mathrm{H}_{2} \mathrm{PO}_{4}^{-} \rightarrow \mathrm{OH}^{\prime}+\mathrm{OH}-\mathrm{Al}+2 \mathrm{OH}^{-}
$$


LINDSAY et alii (1962) identificaram aproximadamente trinta compostos de fösforo precipitados como produtos da reação de ferti i zantes fosfatados com o solo. A natureza dos produtos da reação solo-fosfato depende, sobrétudo, das condições de acidez durante a dissolução do fertilizante. No caso do superfosfato, o fosfato monocälcico monohidratado è transformado em fosfato dicälcico dihidratado $\left(\mathrm{CaHPO}_{4} \cdot 2 \mathrm{H}_{2} \mathrm{O}\right)$ ou ainda $\left(\mathrm{CaHPO}_{4}\right)$, dependen do ido teor de umidade do solo, e subsequente liberação de $\mathrm{H}_{3} \mathrm{PO}_{4}$, resultando numa solução saturada de $\mathrm{H}_{2} \mathrm{PO}_{4}^{-}(\mathrm{pH}=1,5)$ no local de aplicação do fertilizante, de acordo com a seguinte reação:

$$
\mathrm{Ca}\left(\mathrm{H}_{2} \mathrm{PO}_{4}\right)_{2} \cdot \mathrm{H}_{2} \mathrm{O}+\mathrm{H}_{2} \mathrm{O} \rightarrow \mathrm{CaHPO}_{4} \cdot 2 \mathrm{H}_{2} \mathrm{O}+\mathrm{H}_{3} \mathrm{PO}_{4}
$$

0 fosfato dicälcico, embora, seja menos so

lüvel do que o monocálcico, reage com os compostos de Fe e Al em condições àcidas, resultando na adsorção e precipi tação do fósforo como descritas anteriormente. Estes mecanismos tem grande influência na disponibilidade de fósforo aplicado nos latossolos sob vegetação de cerrado que apresentam, em geral, pH baixo e grandes quantidades de öxidos de Fe e Al. Consequentemente, a caracterização dos fosfatos formados e conhecimento de suas propriedades são de muita importância por representar fontes secundārias de fósforo para as plantas.

o efeito dá calagem na disponibilidade do 
fósforo do solo é bem conhecido (MALAVOLTA, 1976), acreditạ se que nos solos àcidos haja reação entre öxido de ferro hi dratado, do tipo de goetita, 'dando um composto insolúvel.

$$
\mathrm{FeOOH}+\mathrm{H}_{3} \mathrm{PO}_{4} \rightarrow \mathrm{FeOH}_{2} \mathrm{PO}_{4}+\mathrm{H}_{2} \mathrm{O}
$$

a liberação do fósforo pela calagem se processaria pela rea çăo:

$$
2 \mathrm{FeOH}_{2} \mathrm{PO}_{4}+2 \mathrm{Ca}(\mathrm{OH})_{2} \rightarrow 2 \mathrm{FeOOH}+\mathrm{Ca}_{2} \mathrm{H}_{2}\left(\mathrm{PO}_{4}\right)_{2}+2 \mathrm{H}_{2} \mathrm{O}
$$

Como a insolubilidade do P ocorre nos dois extremos da faixa do pH, surge o problema do intervalo em que sobrevēm o mínimo de fixação na reação do solo. os fosfatos básicos de ferro e alumínio têm o mínimo de solubilidade em torno dos pH 3 a 4. Com valores mais elevados do pH, parte do $P$ é liberado e a capacidade de fixação de certo modo, diminuida. Entretanto, mesmo com $\mathrm{pH} 6,5$ ainda se encontra quimicamente combinado com Fe e Al. A medida que - pH se aproxima de 6,0, se inicia a precipitação dos compostos de cálcio e com o pH 6,5 a formação de sais insolúveis de cálcio. Com pH superior a 7,0 formam-se compostos ainda mais insolúveis, como apatita.

Estes fatos parecem indicar que a disponibilidade máxima de fosfatos para os vegetais é obtida quando o pH do solo é mantido na faixa de 6,0 a 7,0. No entanto, convém acentuar que mesmo nesta faixa, a disponibilidade de fosfato poderá ser ainda muito baixa e que os fosfatos solú veis adicionados poderão ser imediatamente fixados pelos so los.

A elevação do pH pelo uso de calcário em solo àcido, aumenta a solubilidade dos fosfatos de ferro e 
alumínio e consequentemente a possibilidade de se formarem fosfatos de cálcio mais solüveis; alēm disso, os iônios $\mathrm{OH}^{-}$ mais abundantes que resultam da calagem competem com $\mathrm{H}_{2} \mathrm{PO}_{\overline{4}}^{-}$ (adsorvido ou fixado) por posiçöes de troca, liberando fósfo ro disponivel para as plantas (MALAVOLTA, 1976).

A influência da elevação do pH do solo median te uso de calcário, no aumento de fósforo assimilável pode ser tão grande que faz desaparecer a necessidade da adubação fosfatada; se o solo possuir uma reserva suficiente de fosfạ tos näo disponíveis, a calagem poderá libertar o elemento em quantidade suficiente para atender às necessidades da planta (JORGE, 1983).

Uma das medidas sugeridas por FASSBENDER (1975), para reduzir a fixação de fösforo, baseia-se na diminuição da velocidade de dissolução dos fertilizantes fosfatados, de modo a manter, por mais tempo, uma liberação continua e con $\underline{s}$ tante de fósforo para as plantas. Desse modo, pode-se esperar bom efeito dos fosfatos naturais aplicados em solos äcidos, pela sua solubilização lenta na solução do solo. Entretanto, devido à falta de ação fertilizante destes fosfatos logo após sua aplicação, pode prejudicar severamente a primeira cultura após a adubação (VOLKWEISS e VAN RAIJ, 1976).

E possivel que os fosfatos naturais parcial mente solubilizados aplicados em solos de cerrado, apresen tam resultados imediatos semelhantes aos fosfatos monocälcicos quanto aos seus efeitos sobre o solo e a planta. Possi - 
velmente, porque ao processar a solubilização parcial desses fosfatos naturais, há formação de fosfato bicālcico (ALCARDE e MALAVOLTA, 1982).

\subsection{Fatores que afetam a eficiencia dos fertilizantes fosfatados}

A conveniência da aplicação de fosfatos menos solūveis na agricultura depende de certos fatores que vão determinar a sua eficiência como fertilizantes.

\subsubsection{Fatores inerentes ao fosfato}

Basicamente, os fertilizantes fosfatados dife renciam-se de acordo com sua solubilidade em $\mathrm{H}_{2} \mathrm{O}$, em solúveis, pouco solūveis e insolúveis, sendo os mais comuns os superfosfatos, termofosfatos e fosfatos naturais, respectiva mente. Mais recentemente, desenvolveu-se nas indústrias nacionais, um processo que consiste no menor uso $(=1 / 3)$ de ácido que é exigido para converter todo fosfato de rocha fos fatada para superfosfato. Como resultado desse processo, sur giu no mercado brasileiro os fosfatos parcialmente acidula dos, de solubilidade em citrato intermediária entre os super fosfatos e fosfatos naturais. Desse modo, é possivel que os fosfatos naturais parcialmente acidulados quando aplicados em solos ácidos, produzem reações que levam a uma diminuição da velocidade de dissolução do fertilizante, de modo a prolongar a liberação de fósforo para as plantas.

De fato, os resultados experimentais a ni- 
vel de campo e condições controladas tem confirmado esta hipōtese. Segundo ASHBY et alì -(1966), o efeito favorável dos fosfatos de rocha parcialmente acidulados se deve a um suprimento inicial adequado de fösforo solüvel para ötimo crescimento das plantas, e ao $\mathrm{H}_{3} \mathrm{PO}_{4}$, produzido pela hidrólise do fosfato monocálcico, que reage com rocha fosfa tada não tratada do fosfato parcialmente acidulado, aumen tando a disponibilidade de fósforo. A baixa acidez produzida no solo pelo fosfato parcialmente acidulado resulta em uma menor atividade dos íons Fe e Al e, por conseguinte, nu ma menor fixação de fösforo disponivel comparado ao super.. fosfato.

A solubilidade dos fosfatos naturais ou par cialmente solubilizados tem uma infiluência marcante na eficiência relativa destes fosfatos. No Brasil, a solubilidade tem sido medida através da extração de fósforo em soluções de ácido cítrico a $2 \%$, e citrato neutro de amônio.

Portanto, a solubilidade depende do extrator e da relação fosfato: extrator. A partir de 1975, estabeleceu-se como método oficial, a extração em ácido cîtrico a $2 \%$ na relação adubo: solução $1: 100$.

Contudo, essas soluções extratoras têm apre sentado limitações e permitido resultados contravertidos so bre a eficiência agronómica de certos fosfatos (GOEDERT e LOBATO, 1980). Explicações para este fato são encontradas no trabalho de LEHER e MCCLELLAN (1972). Segundo estes au- 
tores, existem fosfatos naturais com diferentes concentrações de apatita, o que equivale dizer a solubilidade de um fosfa to em citrato está relacionada principalmente com a compos ção mineralógica e, virtualmente, independe do seu teor de $\mathrm{P}_{2} \mathrm{O}_{5}$. As substiuições isomörficas que ocorrem na estrutura da apatita alteram a sua solubilidade. A medida que aumenta - grau de substituição de uma apatita, principalmente do $\mathrm{PO}_{4}^{3-}$ por $\mathrm{CO}_{3}^{-2}+\mathrm{F}^{-}$e a eliminaçäo do fluor da molécula, diminui a solubilidade desta no solo. Como consequência, a so lubilidade de um fosfato natural em citrato tem sido redef nida em uma base absoluta, com objetivo de eliminar efeitos casuais dos teores de $\mathrm{P}_{2}{ }^{0} 5$ entre diferentes fontes. 0 indice de Solubilidade Absoluta em Citrato (ACS) de uma dada fonte de fósforo é definido pela relação entre o teor de $\mathrm{P}_{2}{ }^{0}{ }_{5}$ solúvel em citrato e o teor de $\mathrm{P}_{2}{ }^{0}{ }_{5}$ da composição da apatita, como segue:

$$
\text { ACS }=\frac{\text { cit. Sol } P_{2} \mathrm{P}_{5}(\%)}{\% \text { de } \mathrm{P}_{2} \mathrm{O}_{5} \text { da apatita }}
$$

o tamanho do grânulo constitui outro fator importante. A eficiència dos fosfatos naturais aumenta à me dida que aumenta o grau de finura das particulas, devido à sua baixa solubilidade. 0 efeito do tamanho das partículas do fosfato Sechura sobre a produção de matéria seca e teor de $\mathrm{P}_{2} \mathrm{O}_{5}$ em capim sudan, foi estudado por FASSBENDER (1967). observou-se que as frações de 1.000 a 200 microns proporcio naram as maiores produções e uma tendência de maiores teo- 
res de $\mathrm{P}_{2} \mathrm{O}_{5}$ no tecido vegetal, com a diminuição do tamanho das particulas.

$$
\text { Em contraste com os fosfatos naturais, para }
$$
as fontes sọlúveis espera-se melhor resultado em solos ácidos quando são granulados e aplicados em linha, pois regula a taxa de dissolução. Em um estudo realizado por Suārez, citado por FASSBENDER (1275), em solos com alta capacidade de fixação de fósforo utilizando fertilizantes radioativos marcados, com diâmetros dos grânulos de 0,$5 ; 2 ; 3 ; 6$ e 12 $\mathrm{mm}$, encontrou que o tamanho ótimo é de aproximadamente $8 \mathrm{~mm}$ e que no caso do Ultissolo estudado, o aproveitamento do $p^{32}$ aumentou de 3 para $11 \%$. Infelizamnte, no Brasil, tem-se dado pouca ênfase às pesquisas dessa natureza.

Outro fatorique afeta a disponibilidade de fósforo dos fosfatos naturais é o teor de fluor (BRAGA,1970). Quanto mais baixo é o teor de fluor dos fosfatos naturais, mais aceitáveis são os mesmos para a fabricação de fertilizantes e para seu uso direto na àricultura.

Não se encontram dados sobre este fator em relação à maioria dos fosfatos brasileiros. FASSBENDER(1967) cita para os fosfatos de Araxá e Alvorada os valores de $3,28 \%$ e $2,70 \%$, respectivamente. Para efeito de comparação, são citados os seguintes teores de fluor encontrados em outros fosfatos: Sechura $=2,11 \% ;$ Flörida $3,5 \% ;$ Gafsa $=2,56 \%$ e Marrocos $=4,05 \%$. Estes valores segundo FASSBENDER (1975), 
não devem ultrapassar 5\%. Altos teores de óxidos de Al e Fe também depreciam a qualidade dos fosfatos naturais.

\subsubsection{Fatores inerentes ao solo}

A acidez do solo, composição mineralógica,os teores de fósforo e cálcio, textura e matéria orgânica, são fatores que afetam a dissolução de fosfatos no solo.

Ao contrārio dos fosfatos solúveis em ăgua, a eficiencia dos fosfatos de baixa solubilidade tem sido menor quando se faz a correção da acidez do solo através da calagem. Trabalho realizado por GOEDERT e LOBATO (1980) caracteriza o efeito favorável da acidez do solo na dissolução dos fosfatos naturais. Verificaram que, aumentando o $\mathrm{pH}$ de 4,8 a 5,9 através da calagem, a eficiência do fosfato de Patos diminuiu e a do superfosfato triplo aumentou em termos de produção de soja, atingindo valores máximos com is t de calcārio por hectare. A interação negativa, calagem e fos fato de Araxá, foi também observada por BRAGA (1969), quando calagem a pH 6,5 praticamente eliminou qualquer efeito a curto prazo, de até $300 \mathrm{~kg} \mathrm{P}{ }_{2}{ }_{5} /$ ha, para a cultura do feijão.

o calcário, além de elevar o pH do solo, adi ciona íons $\mathrm{Ca}^{+2}$ à solução. Solos com altos teores de $\mathrm{Ca}^{+2}$ na solução do solo tendem a solubilizar mais lentamente os fosfatos naturais, jä que o $\mathrm{Ca}^{+2}$ é um dos produtos da reação do fosfato no solo (KORNDORFER, 1978). Da mesma forma, alta con 
centração de $\mathrm{H}_{2} \mathrm{PO}_{\bar{l}}^{-}$na solução, mais lentamente serä a disso lução dos fosfatos.

Solos com semeltiante mineralogia da argila fixarão mais fósforo com um aumento no seu teor de argila. Vários estudos no Brasil têm mostrado essa relação com o teor de argila. Woodruff e Kamprath (1965), citados por LoPES (1977a) encontraram valores de 18, 104 e 342 ppm de adsorção máxima de fósforo para Ultissol com $2 ; 7,5$ e $38 \%$ de argila, respectivamente. LOPES (1977b) encontrou que os aumentos nos teores de argila de 44 amostras de solos sob vegetação de cerrado, causaram variações mais acentuadas das cargas positivas do que das cargas negativas líquidas, evi denciando que a porcentagem de argila desses solos é um bom parâmetro para estudar eficiencia de fertilizantes fosfatados.

A matēria orgânica tem influência através de sua contínua dissociação, criando cargas elétricas negativas, bloqueando as hidroxilas nas superficies dos öidos de $\mathrm{Fe}$ e Al, imobilizando-as de modo a não formar precipitado com - $\mathrm{H}_{2} \mathrm{PO}_{4}^{-}$, reduzindo a adsorção do $\mathrm{H}_{2} \mathrm{PO}_{4}^{-}$e consequentemente a disponibilidade de fósforo é aumentada (MALAVOLTA, 1976).

\subsubsection{Fatores inerentes à planta}

Atualmente, è reconhecido o fato de que as espécies ou cultivares dentro de uma mesma espécie variam grandemente na sua habilidade de utilização de fösforo. os 
resultados obtidos por FAGERIA e BARBOSA FILHO (1981) mostram que os cultivares de arroz diferem em suas respostas à condições de estresse de fósforo, e algumas têm excelente tolerância ao baixo nivel deste nutriente no solo. Este fato sugere, portanto, a necessidade de diferentes recomendaf̧ões de adubação fosfatada no mesmo solo para cultivares diferentes.

As diferenças entre espécies devem estar re lacionadas às suas demandas por cálcio e fósforo, que alteram a composição da solução do solo na interface raiz-solo. Plantas de crescimento räpido necessitam de taxa mais alta de acumulação de fósforo dentro da planta, para manter este crescimento. Plantas de sistema radicular extensivo terão maior demanda de fósforo por unidade de comprimento de raiz do que as de sistema radicular de comprimento limitado.

\subsection{Resultados experimentais obtidos com fosfatos}

naturais parcialmente solubilizados

Embora a maioria dos trabahos com fosfatos naturais parcialmente solubilizados tenham sido conduzidos em casa-de-vegetação, os resultados obtidos principalmente em solos ácidos são altamente favoráveis à sua utilização.

ASHBY et alii (1966), estudando a acidulação parcial do fosfato natural da Flörida $\operatorname{com~H}_{3} \mathrm{PO}_{4}$ a $0,12,5$, 
25,50 e $100 \%$ do total de àcido exigido para converter todo o fosfato de rocha para superfosfato triplo, observaram na maioria dos casos, um aumento na produção de matēria seca de centeio e fósforo absorvido com o elevado nível de acidu lação. o nivel de 50\% de acidulação, mostrou-se equivalente ao superfosfato triplo nos dois solos usados, mostrando um efeito ainda maior no solo de pH 6,0 do que ao de pH 7,0.

LUTZ (1971), em experimento de campo com mi Iho (zea mays L.), com duração de três anos, concluiu que o superfosfato concentrado foi superior à rocha acidulada a $20 \%$ com $\mathrm{H}_{3} \mathrm{PO}_{4}$ em termos de produção de grãos, particularmen te nos niveis mais baixos de fósforo aplicado, enquanto na mais alta dose de fósforo $(100 \mathrm{~kg} / \mathrm{ha})$ constatou equivalên cia entre os materiais utilizados e que a rocha acidulada a $20 \%$ foi a fonte de fósforo mais econômica.

Dados apresentados por SHINDE et alii (1978), mostraram que fosfatos de rocha parcialmente acidulados com $\mathrm{HCl}$ e $\mathrm{H}_{2} \mathrm{SO}_{4}$ resultam na formação de uma mistura de fosfato solūvel em āgua (possivelmente dicālcico) e insolúvel. Tambèm, observaram que, em geral, aumentando a porcentagem de acidulação da rocha fosfatada resultou no aumento da quantidade de fósforo solúvel em àgua e àcido cítrico, e que o nível de $50 \%$ de acidulação com $\mathrm{HCl}$ ou $\mathrm{H}_{2} \mathrm{SO}_{4}$ foi o mais ade quado para o arroz irrigado, em termos de teor disponível de fósforo no solo, produção de matēria seca e absorção de fösforo. 
FERREIRA e KAMINSKI (1.979) verificaram uma eficiência, em termos de produção de matéria seca de soja, do fosfato de patos em relação no superfosfato triplo, de 60 e $61 \%$ quando acidulado, respectivamente, com 25 e $50 \%$ de $\mathrm{H}_{3} \mathrm{PO}_{4}$ e aplicados num Podzölico Vermelho-Amarelo, e de 68 e $80 \%$ quando aplicados no solo Laterítico Bruno-Avermelhado eutrófico, ambos corrigidos para $\mathrm{pH}$ 6,0. Ensaios conduzidos por NOVAES et alii (1983) visando verificar o comportamento do Fosfato de Araxá Parcialmente Solubilizado (FAPS), quanto ao fósforo absorvido pelo capim Andropogon,observaram uma eficiência do FAPS ligeiramente inferior comparada ao super fosfato Simples. FREIRE et alii. (1983) observaram eficiência relativa do fosfato Aude parcialmente acidulado, intermediā ria a das fontes solüveis e naturais e eficiência semelhante do fosfato Superaude em relação ao superfosfato triplo, em Latossolos Vermelho-Amarelo, argiloso, para a produção de matēria seca de sorgo. Os autores relatam que a calagem efetuada no Latossolo de Uberaba prejudicou a eficiência dos fosfatos, confirmando o fato de que o aproveitamento da acidez natural dos solos para acelerar a solubilidade dos fosfatos naturais ou parcialmente solubilizados parece uma boa estratégia a ser seguida em solos àcidos do cerrado.

Em ensaios com as culturas de soja, arroz e milho, cultivadas em campo, em Latossolo Vermelho-Amarelo e Latossolo Roxo, com pH corrigido para 6,1, MALAVOLTA et alii (1981) compararam a eficiência agronômica do fosfato de Ara xá parcialmente acidulado (FAPS) em relação ao superfosfato 
simples. Os autores não encontraram diferenças significat vas de produção, no primeiro ano, para as doses de 60 e 120 $\mathrm{kg} / \mathrm{ha}$ de $\mathrm{P}_{2} \mathrm{O}_{5}$ total, usando FAPS e $90 \mathrm{~kg} / \mathrm{ha}$ de $\mathrm{P}_{2} \mathrm{O}_{5}$ na forma de superfosfato simples, Resultados semelhantes foram ob tidos também para a produção de cana-planta nas doses de 160 e $120 \mathrm{~kg} / \mathrm{ha}$ de $\mathrm{P}_{2}{ }^{0}{ }_{5}$, usando FAPS e superfosfato simples, respectivamente (MALAVOLTA et alii, 1982).

No caso do arroz de sequeiro cultivado em Latossolo Vermelho-Escuro, foi obtida uma eficiência de $72 \%$ para o fosfato Aude parcialmente acidulado, em relação ao superfosfato triplo (EMBRAPA, 1981). Resultados de dois anos de avaliação dos fosfatos de Patos parcialmente acidulado (FPPA) e fosfato de Araxà parcialmente solubilizado (FAPS), em relação ao superfosfato triplo, medida pelo ren dimento do arroz de sequeiro, em Latossolo Vermelho-Escuro, pH 4,9, foram apresentados por BARBOSA FILHO et alii(1983). Concluiram que a produção de $90 \%$ do rendimento mäximo foi obt i da pela combinação de $200 \mathrm{~kg} / \mathrm{ha}$ de $\mathrm{P}_{2} \mathrm{O}_{5}$, na forma de FPPA ou FAPS, aplicado a lanço e $60 \mathrm{~kg} / \mathrm{ha}$ de $\mathrm{P}_{2} \mathrm{O}_{5}$ na forma de su perfosfato triplo aplicado no sulco de plantio. 0 efeito residual dos fosfatos parcialmente acidulado foi evidente no segundo ano, quando as aplicações anuais de superfosfato triplo no sulco não mostraram aumentos de produção.

Comparando a eficiência dos três fosfatos aplicados no sulco de plantio, os autores observaram uma 
tendência de comportamento muito semeltiante nos dois anos de cultivo. Porém, para se obter efeito semelhante ao do superfosfato triplo, as doses de ambos fosfatos parcialmente acidulados têm que ser maiores.

\subsection{Fracionamento de fósforo e fösforo disponível do} so10

Do ponto de vista de disponibilidade, o $P$ total tem pouco significado para as plantas, pois depende da forma em que o fósforo se encontra no solo. De acordo com o trabalho de CHANG e JACKSON (1957), em latossolo, o P-Fe foi encontrado representando mais de $80 \%$ do p-total.

JORGE e VALADARES (1969) determinaram as formas em que se encontra o P nativo de dez solos importantes do Estado de São Paulo, e concluiram que a maior parte do p-total achạ se ligada ao ferro, com exceção da Terra Roxa Estruturada que apresentou alto teor de $\mathrm{P}$ na forma mais facilmente apro veitável, isto è, o $P-C a$.

CABALA E FASSBENDER (1970) fracionaram o Ptotal de 54 amostras correspondentes a 8 solos representat vos da região cacaueira da Batia, e concluiram que a defi ciência generalizada de fósforo na região está associada a predominância de $P-F e(24,8 \%)$ e fosfatos inativos, ou seja, P-solúvel redutível e P-ocluso $(39,5 \%)$. O P-Ca e P-Al repre sentam apenas $9,5 \%$ e $2,0 \%$, respectivamente, do p-total. 
BRAGA e DEFELIPO (1972a). encontraram para amostras superficiais, de Latossolo Vermelho Escuro, coleta do em nove locais do Triângulo Mineiro, que a fração de $P$ inorgânico presente em maior quantidade è a solūvel em redụ tor, seguindo-se a ligada a ferro (P-Fe), a cálcio (P-Ca)e, por ültimo, a ligada a alumínio (P-Al).

ALMEIDA NETO (1979) estudou o destino do P aplicado na forma de superfosfato em 10 unidades de solos do Estado de Goiás, com características diversas, observando uma uniformidade da distribuição, em concentração, das diferentes frações de $P$ nos solos, apresentando em 5 solos a seguinte sequência: $\mathrm{P}$-redutível $>\mathrm{P}-\mathrm{Fe}>\mathrm{P}-\mathrm{Ca}>\mathrm{P}-\mathrm{Al}>\mathrm{P}-$ solüvel e em outros 5 solos observou-se apenas uma inversão passando o P-Ca a ser maior que o P-Fe. Portanto, a quase totalidade dos resultados concordam com a afirmação de CHANG e JACKSON (1957) de que em solos altamente intemperizados ocorre uma predominância de $P-F e$ e de formas inativas de fösforo, ou seja, P-redutível solūvel e P-ocluso.

A disponibilidade de fósforo para as plantas è avaliada, em geral, através de mëtodos químicos desenvolvidos estritamente com esta finalidade. Estes métodos devem atender pelo menos a dois critērios: (1) devem extrair toda ou uma parte proporcional das formas disponiveis de fösforo em solos com amplas diferenças em propriedades,

e (2) as quantidades extraidas devem correlacionar com a 
produção e absorção desșe nutriente sob vārias condições (BRAY e KURTZ, 1945). Entretanto, os resultados de experi mentos de campo, nem sempre mostram boas correlações entre os teores de fósforo dos solos e a produção das culturas, devido à natureza química dos extratores e, principalmente, em se tratando de solos com propriedades diferentes e quando são empregados fosfatos de baixo valor fertilizante (SFRE Do et alii, 1979; CABALA e SANTANA, 1983a; RAIJ, 1978).

Vários métodos de extração de fósforo do so lo são usados atualmente no Brasill, destacando-se os de Mehlich, Bray 1, Bray 2, 01 sen e mais recentemente, a técni ca de extração pela resina trocadora de ânions.

A técnica de fracionamento de CHANG e JACKSoN (1957) tem sido empregada para correlacionar formas de fósforo no solo com métodos de extração e absorção pelas plantas (BIASI, 1978; TANAKA et alii, 1981). Experimentos com esta finalidade foram conduzidos em um vertissolo por PEREIRA e FARIA (1978), com a cultura do milho. Altos coeficientes de correlação foram observados entre as diversas formas inorgânicas de fósforo com os teores extraídos pelos métodos de Bray l, Mehlich, Olsen, água destilada e o absor vido pelo milho.

FASSBENDER et alii (1968), estudando oito solos com capacidade de fixação de 28 a $72 \%$ de $p$ solúvel ex traído pelo método de Bray-2. observaram que os solos retinham progressivamente mais fósforo na forma de P-Al do que 
P-Fe, a medida que aumentava a porcentagem de fixação de fósforo. Isto sugere que o P-Al nesses solos representa melhor a forma de P "disponivel" para as plantas do que $P-F e$, o que foi comprovado pelas correlações positivas encontra das com $P$ absorvido pelas plantas de aveia.

GOEDERT et alie $(1971)$ ao estudarem alguns aspectos relacionados com as formas de $\mathrm{P}$ do solo e a cultura do arroz irrigado, constataram uma relação estreita entre produção de arroz e os teores de $P$ nas formas de $P$ disponível pelo método de Mefilich e P-Fe, sendo esta fração considerada a fonte mais importante de P "disponivel" para a cultura do arroz.

DELAZARl et alie (1980), ao estudarem a dis ponibilidade de fósforo em solos representativos do Estado do Espirito Santo, observaram que as menores quantidades de fósforo estavam na forma de $\mathrm{NH}_{4} \mathrm{Cl}-\mathrm{P}$ e, as de maior expressão, foram em ordem decrescente $P-F e, P-A l$ e $P-C a$, o que re flete certo modo, um grau avançado de intemperismo dos solos estudados. Os teores de fósforo extraídos pelos métodos Mehlich, Bray 1 , Bray-2 e do $\mathrm{H}_{2} \mathrm{SO}_{4} 0,05 \mathrm{~N}$, correlacionaram significativamente entre si e com as squantidades de fósforo oriundas do fracionamiento, com exceção do $\mathrm{NH}_{4} \mathrm{Cl}-\mathrm{P}$. Encontra ram também correlação significativa ao relacionar a quantidade de fósforo absorvido pelas plantas de sorgo do trata mento sem fósforo com as quantidades desse nutriente extra das pelos diferentes extratores. 
A calagem dos solos pode alterar profunda mente a solubilidade do fosfato, dependendo, principalmente do extrator usado. BRAGA e DEFELIPO (1972a) encontraram que a forma de P "disponivel" em solos com calagem, obtida com extrator Bray-1 e com o Bray-2, correlaciona com a forma de P-Fe, enquanto os extratores de Mehlicti, Bray-1 e Bray-2, correlacionaram com a forma de P-Al em solos com e sem calcário; e o extrator 0lsen somente correlacionou com P-Al em amostras sem calagem. A forma de P-Ca não correlacionou para estes solos, com os teores de p "disponivel", obtidos com nenhum dos extratores estudados. BRAGA e DEFELIPO (1972b) observaram um aumento do fósforo "disponivel" obtido com $\mathrm{H}_{2} \mathrm{SO}_{4} 0,05 \mathrm{~N}$ e que este aumento foi, possivelmente, causado pelo maior período de contato do calcärio com o solo, alterando, no sentido $P-A l$ para $P-C a$, o equilibrio entre as for mas de $P$, o que concorda com os dados de FASSBENDER et alii (1968); CABALA e FASSBENDER (1971) e BRAGA e DEFELIPO (1972a).

Ainda, de acordo com BRAGA e DEFELIPO(1972b), a fração de P-Fe foi a que melhor correlacionou com o peso das plantas de painço, porcentagem de $P$ no material vegetal e fösforo absorvido, após colheita. Encontraram também, que as quantidades de $P$ absorvidos pelo painço correlaciona ram de modo linear e positivamente com os teores de P "disponivel" obtidos com os extratores Bray-l e 01 sen.

TANAKA et alii (1981), ao estabelecerem o melhor extrator de fösforo quando se utiliza o fosfato Patos 
de-Minas em Latossolo Roxo distrófico, mostraram que o métọ do Mehlich apresenta grande poder de extração de fósforo, tanto na presença como na ausência de calcário. Concluiram que o extrator Bray-2 modificado foi o que melhor estimou a disponibilidade de fósforo do fosfato Patos-de-Minas, por correlacionar significativamente com as frações $P-A l$ e $P-F e$ e também com a produção de matéria seca e fósforo absorvido pelo milho.

BAHIA FILHO et alie (1982), estudando a relação dos teores de fósforo disponíveis extraídos pelos extratores Bray-1, Bray-2, Mehlich e 01 sen com as formas inor gânicas após aplicação de fosfatos solūveis e de rocha em Latossolo Vermelhor Escuro textura argilosa, fase cerrado, verificaram, no caso dos fosfatos naturais, que a forma P-Ca removida pelo Mehlich era constituida de fosfato de cālcio proveniente de fertilizante aplicado e que ainda não reagiu com o solo. o mesmo comportamento se verificou com o extrator Bray-2. No caso do superfosfato triplo, a remoção preferencial foi P-Al, tendo em vista a maior ativi dade dessa forma em solos àcidos em comparação a P-Ca.

AMER et alii (1955) propuseram o uso de resinas anionicas para extrair o fosforo do solo. Esta tēcni ca baseia-se no intercâmbio reversível de ions entre o material de troca iónica (resinas) e o soluto, no qual não há mudança permanente na estrutura da resina. Uma van- 
tagem da troca iônica sobre outros processos é a maior efi ciência deste extrator. Assim, durante o processo de troca iônica, o fósforo do solo é trocado por uma quantidade equi valente de cloreto. Posteriormente, a resina carregada de fósforo é tratada com HCl para remoção do fósforo e, logo após, a resina pode ser tratada com uma solução de $\mathrm{NaCl}$ que lhe restitui o ânion cloreto sendo possivel novo ciclo de operação. Este procedimento é, comumente, chamado regeneração.

0 uso da resina trocadora de ânions como mé todo de avaliação da disponibilidade de fósforo no solo para as plantas, tem sido pesquisado em todo o mundo há mais de um quarto de século. AMER et alie (1955), trabalhando em laboratório com 16 solos, encontraram coeficientes de correlação de 0,95 e 0,91 entre fósforo adsorvido pela res na em duas horas e fósforo avaliado pela diluição isotópica e solução HCl $0,25 \mathrm{~N}+\mathrm{NH}_{4} \mathrm{~F} 0,03 \mathrm{~N}$ (Bray-Kurtz), respectiva mente. Dados obtidos por COOKE e HISLOP (1963), em experi mentos em vasos, demonstraram que a quantidade de fósforo extraído pela resina foi altamente correlacionada $(r=0,91)$ com a quantidade de fósforo absorvido pelas iplantas de centeio.

De acordo com os dados apresentados por HI LOP e COOKE (1966), o método da resina foi testado, entre outras, com a solução extratora de 01 sen, em solos calcários 
e não calcários. Os coeficientes de correlação obtidos entre as quantidades de fósforo extraídas pelos dois métodos foram 0,830 e 0,877 para os solos calcários e não calcários, respectivamente. Segundo estes autores, a técnica de extração de fósforo pela resina reflete ambos os fatores capacidade e intensidade de fósforo no solo.

PALMA e FASSBENDER (1970), avaliando a disponibilidade de fósforo para tomateiro, em 40 solos da América Central, demonstraram que o método da resina se mostrou superior aos extratores Bray 1, Mehlich, 01 sen, Saunder modificado, Eguer-Riehur e potencial fosfato, pela alta correlação $(0,93)$ obtida entre o fósforo extraído pela resina em 18 horas e fósforo absorvido pelas plantas. Ainda segundo esses autores, e AMER et alli (1955), è importante ressaitar que a técnica de extração pela resina aniônica apresen ta certas vantagens em relação aos métodos convencionais pẹ la ausência do solvente químico, reproduz com mais precisão o mecanismo de absorção de fósforo pelas raizes e eliminam adsorção secundāria dos ions fosfato durante a extração.

RAlJ (1978), mediante extensa revisão bibliográfica, demonstrou a superioridade do método da resina, em relação a uma série de extratores químicos de uso comum no Brasil.

No Brasil, o emprego da resina aniônica como indice de disponibilidade de fósforo para as plantas, te ve inicio com os trabalhos de CABALA (1979) e RAIJ e DIEST (1980). 
RAIJ et alie (1982), trabalhando com solos provenientes de ensaios com milho e algodão, no Estado de São Paulo, concluiram que o método da resina se mostrou superior aos extratores de 01 sen, Bray $\mathrm{I}$ e do $\mathrm{H}_{2} \mathrm{SO}_{4} 0,05 \mathrm{~N}$. Recentemente, a resina aniônica foi implantada como técnica rotineira de extração de fósforo no Estado de São Paulo, pelo laboratório de Análises de Solos do Instituto Agronômico de Campinas e, posteriormente, pelos Laboratórios do Departa mento de Quimica e de Solos Geologia e Fertilizantes da Esco la Superior de Agricultura "Luiz de Queiroz". (ESALQ). Da mes ma forma, no Centro de Pesquisa do Cacau, vem sendo testado o método da resina trocadora de ãnions, visando à substitul ção gradual do extrator Mehlich nas análises de solo (CABALA e SANTANA, 1983a). 


\section{MATERIAL E METODOS}

\subsection{Caracteristicas dos solos e fosfatos usados nos.}

\section{experimentos}

As amostras de solo, utilizadas neste traba Iho foram coletadas em àreas ainda sob vegetação de cerrado, do Centro Nacional de Pesquisa de Arroz, Feijão (Goiãnia-Go) e da Estação Experimental de Anāpolis (Anäpolis - Go), carạ terizados, respectivamente, como Latossolo Vermelho Escuro diströfico, textura argilosa (LEd) e Latossolo Vermelho Amarelo distrófico, textura franco argilosa (LVd). Segundo o Sistema de Classificação (Soil Survey Staff, 1975), os latossolos da regiãa dos cerrados, no Brasil, são classificados como 0xisols, constituidos por um epípedon ochrico, e um horizonte de sub-superficie $0 x i c o$. Neste trabalho, os solos receberam as denominações de LEd e LVd, respectivamente.

$$
\text { As amostras foram coletadas numa profundida }
$$
de até $20 \mathrm{~cm}$ que, após secadas ao ar, foram passadas por pe- 
neira com malha de $2 \mathrm{~mm}$. As amostras de solo foram analisadas objetivando sua caracterização física e química, cujos resultados são mostrados nas Tabelas 1 e 2.

Com exceção da fração areia, há uma varia ção nos teores de argila e silte, quando se compara os dois solos.

Tabela 1 - Algumas caracteristicas físicas dos solos utilizados $(0-20 \mathrm{~cm})$

\begin{tabular}{|c|c|c|c|c|c|c|}
\hline Solos & $\begin{array}{l}\text { argila } \\
\text { dispersa } \\
\text { em } \mathrm{H}_{2} \mathrm{O}\end{array}$ & argila & silte & areia & $\begin{array}{l}\text { densida- } \\
\text { de apa- } \\
\text { tente }\end{array}$ & $\begin{array}{l}\text { classe } \\
\text { tex- } \\
\text { tural }\end{array}$ \\
\hline & ---- & --- & $\%$ & $--\cdots$ & $\mathrm{g} / \mathrm{cm}^{3}$ & \\
\hline LVd & 15,6 & 30,2 & 29,1 & 40,7 & 1,20 & \multirow{2}{*}{$\begin{array}{r}\text { franco } \\
\text { argillosa } \\
\text { argi losa }\end{array}$} \\
\hline LEd & 25,0 & 47,1 & 13,5 & 39,4 & 1,19 & \\
\hline
\end{tabular}

Em relação ao suprimento de nutrientes (Tabela 2) ambos solos apresentam na camada superficial baixa disponibilidade, sendo naturalmente ācidos, com baixos teores de potássio, cálcio e magnēsio e de matēria orgânica. A relação $\mathrm{Ca}^{++} / \mathrm{Mg}^{++}$ë de aproximadamente 3,8 e 2,8 para o LVd e LEd, respectivamente. Estes dados demonstram uma predominância do cálcio sobre o magnésio no complexo de troca. os valores de alumínio trocável e percentagem de saturação de alumínio, encontrados para os dois solos, não oferecem problemas para a cultura do arroz de sequeiro (FAGER/A, 1984). 
Tabela 2 - Características químicas dos solos utilizados. Amostras de terra coletadas de 0 a $20 \mathrm{~cm}$ de profundidade

\begin{tabular}{|c|c|c|c|c|}
\hline \multirow{2}{*}{ Caracteristicas } & \multirow{2}{*}{ Unidade } & \multicolumn{2}{|c|}{ Solos } & \multirow{2}{*}{ Método } \\
\hline & & LVd & LEd & \\
\hline M. 0. & $\%$ & 1,66 & 2,74 & Walkley-Black \\
\hline $\mathrm{Ca}^{++}$ & $\mathrm{meq} / 100 \mathrm{~g}$ & 0,60 & 0,56 & $\mathrm{KCl}$ IN \\
\hline $\mathrm{Mg}^{++}$ & 11 & 0,16 & 0,20 & $\mathrm{KCl} I \mathrm{~N}$ \\
\hline $\mathrm{K}^{+}$ & $" 1$ & 0,07 & 0,10 & Mehlich \\
\hline $\mathrm{Al}^{+++}$ & $" 1$ & 0,59 & 0,56 & $\mathrm{KCl} I N$ \\
\hline $\mathrm{H}^{+}+\mathrm{Al}^{+++}$ & $" 1$ & 3,20 & 5,60 & $\mathrm{Ca}(\mathrm{AOC})_{2} \mathrm{pH} 7$ \\
\hline Soma de bases & $" 1$ & 0,83 & 0,86 & Calculado \\
\hline CTC & $" 1$ & 4,03 & 6,46 & Calculado \\
\hline Saturação de Al & $\%$ & 41,50 & 39,40 & Calculado \\
\hline $\mathrm{pH} \quad(1: 2,5)$ & - & 4,90 & 4,70 & em $\mathrm{H}_{2} \mathrm{O}$ \\
\hline p"disponivel" & $\mu \mathrm{g} P / \mathrm{cm}^{3}$ & 2,18 & 4,36 & Resina \\
\hline p"disponivel" & ppm & 1,40 & 2,53 & Bray-1 \\
\hline p"disponivel" & ppm & 1,00 & 1,00 & Mehlich \\
\hline $\mathrm{P}-\mathrm{NH}_{4} \mathrm{Cl}$ & $\mu g \mathrm{P} / \mathrm{g}$ & 8,00 & 6,00 & CHANG \& JACKSON \\
\hline $\mathrm{P}-\mathrm{Ca}$ & $" 1$ & 13,00 & 18,00 & $(1957)$ \\
\hline $\mathrm{P}-\mathrm{Fe}$ & 11 & 45,00 & 52,00 & $" 1$ \\
\hline$P-A I$ & 11 & 35,00 & 35,00 & $" 1$ \\
\hline Outros fosfatos & $" 1$ & 154,00 & 308,00 & Calculado \\
\hline$P$ total & 11 & 255,00 & 419,00 & HESSE (1971) \\
\hline $\mathrm{SiO}_{2}$ & $\%$ & 4,90 & 7,30 & VETORI (1969) \\
\hline $\mathrm{Al}_{2} \mathrm{O}_{3}$ & $\%$ & 18,70 & 22,40 & $\because$ \\
\hline $\mathrm{Fe}_{2} \mathrm{O}_{3}$ & $\%$ & 5,30 & 12,00 & $" 1$ \\
\hline $\mathrm{TiO}_{2}$ & $\%$ & 1,02 & 1,58 & $" 1$ \\
\hline$\because K i$ & - & 0,45 & 0,55 & 11 \\
\hline
\end{tabular}


Entre as frações de $P$ inorgânicas, e considerando os dois solos, observa-se uma variação de dados. A fração P-Fe é a mais comum, seguindo-se a ligada ao alum I nio $(P-A l)$ e por ültimo o cālcio $(P-C a)$.

Os resultados das anālises química e granulométrica dos fosfatos utilizados no experimento, são apresentados na Tabela 3. A solubilidade de um fosfato depende da forma em que o $P$ se encontra e da reação do meio. A acidulação parcial do fosfato natural de Araxá aumenta a solubilização do $\mathrm{P}$ tanto em $\mathrm{H}_{2} \mathrm{O}$ como em ácido cítrico, e produz - gesso como sub-produto do processo de acidulação. o super fosfato Triplo e o de Araxá Parcialmente Solubilizado foram denominados, neste trabalho, de SPT e FAPS, respectivamente.

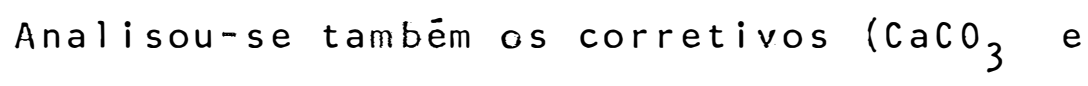
$\mathrm{MgCO}_{3}$ comerciais); dissolvendo-se l g de material finamente moído em $50 \mathrm{ml}$ de $\mathrm{HCl} 0,5 \mathrm{~N}$, titulando-se o excesso com $\mathrm{NaOH}$ $0,25 \mathrm{~N}$ contra indicador fenolftaleina. $0 \mathrm{~s}$ teores de $\mathrm{CaCO}_{3}$ e de $\mathrm{MgCO}_{3}$ foram $89,35 \%$ e $80,30 \%$, respectivamente.

\subsection{Delineamento experimental.}

os tratamentos constituiram-se num arranjo

fatorial $4 \times 2 \times 2 *$, correspondendo a dois solos, duas fontes de fosfato e quatro periodos de incubação que incluem 3 tratamentos com calcário, aplicado a intervalos de 90 dias

* Cada solo foi estudado separadamente para facilitar a interpretação dos resultados. 


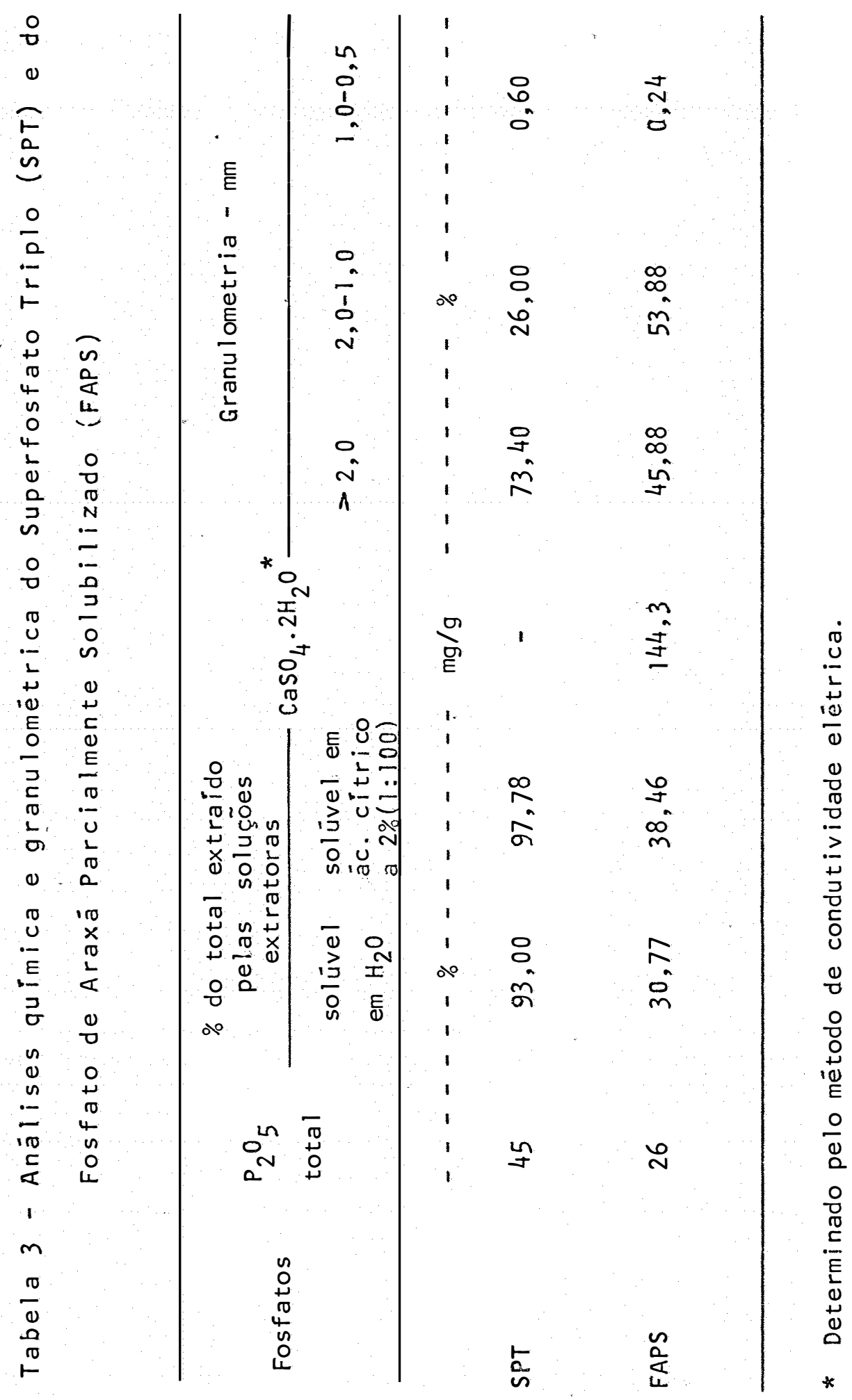


e um sem adição do calcärio mas incubado por 180 dias com FAPS e SPT. O delineamento foi disposto em blocos casualizados com três repetições e a unidade experimental foi constituida por um vaso com $3,0 \mathrm{~kg}$ de terra.

\subsection{Instalação e condução dos experimentos em casa de vegetação}

Antes do plantio do arroz, amostras de $4 \mathrm{~kg}$ de cada solo, com FAPS e SPT foram incubadas em sacos plästicos. Os fosfatos, superfosfato triplo (SPT) e fosfato de Araxá parcialmente solubilizado (FAPS) foram aplicados em forma granular na dose de $150 \mathrm{ppm}$ de $\mathrm{P}$ com base no teor de $\mathrm{P}_{2} \mathrm{O}_{5}$ total revelado pela anälise química (Tabela 3). A terra e o fosfato foram misturados manualmente nos sacos plàsticos, irrigados com āgua destilada até $80 \%$ da capacidă de mäxima de retenção de ccada solo e fechados. As amostras foram incubadas por 180 dias, iniciando a $01 / 08 / 85$ e terminando em 01/02/86. A cada intervalo de 90 dias o calcärio foi aplicado, para isso as amostras respectivas eram secas ao ar, destorroadas e passadas em peneira com malha de $2 \mathrm{~mm}$ e o calcärio era então aplicado em uma mistura de $\mathrm{CaCO}_{3}+\mathrm{MgCO}_{3}$ comerciais na forma de pó, na proporção de 4:1 equivalentes; as necessidades de calcário para a elevação do $\mathrm{pH}$ em $\mathrm{H}_{2} \mathrm{O}$ em torno de 6,5; foram calculadas mediante a correlação entre $\mathrm{pH}$ e a saturação de bases (CATANI e GALLO, 1955). Dessa for ma, se obteve os seguintes períodos de reação entre calcārio e fosfato em dias: 180,90 e 0 . Após a aplicação do 
calcário e água, os solos eram cobertos com sacos plásticos de polietileno preto para evitar a incidencia de luz e, consequentemente, a germinação de sementes ,de ervas daninhas.

Após a incubação, as amostras de solo foram novamente secas ao ar, destorroadas e passadas em peneira de $2 \mathrm{~mm}$ de abertura de malhas e procedeu-se a amostragem de $500 \mathrm{~g}$ de terra para análises. Em seguida, fez-se uma adubação bási ca e uniforme a todos os tratamentos na forma de solução nutritiva contendo a maioria dos nutrientes essenciais às plantas, nas concentrações e quantidades indicadas na Tabela 4. Ainda como adubação básica, aplicou-se nos tratamentos sem calcário, uma solução contendo $\mathrm{Ca}$ e $\mathrm{Mg}$ nas formas $\mathrm{CaCl}_{2} \cdot 2 \mathrm{H}_{2} \mathrm{O}$ e $\mathrm{MgCl}_{2} \cdot 6 \mathrm{H}_{2} \mathrm{O}$, na relação de $4: 1$, em quantidades correspondentes àquelas aplicadas como corretivo, com objetivo de fornecer Ca e Mg como nutrientes para as plantas. Desde que o FAPS apresente na sua constituição o gesso (Tabela 3), adicionou-se aos tratamentos com superfosfato triplo, uma quantidade equivalente de gesso em forma de solução, para eliminar possível efeito do ín acompanhante $\mathrm{SO}_{4}=$

Tabela 4 - Concentrações de $N, K$ e micronutrientes, fontes e suas respectivas quantidades adicionadas no inicio e durante o periodo de crescimento do arroz

\begin{tabular}{cclcc}
\hline Nutriente & $\begin{array}{c}\text { Concentraçäo total } \\
\text { Dpm }\end{array}$ & \multicolumn{1}{c}{ Fonte } & $\begin{array}{c}\text { Inicial } \\
\mathrm{mg} / \text { vaso }\end{array}$ & $\begin{array}{c}\text { Cobertura } \\
\mathrm{mg} / \text { vaso }\end{array}$ \\
\hline $\mathrm{N}$ & $180(60+120)$ & $\mathrm{NH}_{4} \mathrm{NO}_{3}$ & 537 & 1074 \\
$\mathrm{~K}$ & $150(75+75)$ & $\mathrm{KCl}$ & 432 & 432 \\
$\mathrm{~B}$ & 1,0 & $\mathrm{H}_{3} \mathrm{BO}_{3}$ & 17,14 & - \\
$\mathrm{Cu}$ & 1,0 & $\mathrm{CuSO}_{4} \cdot 5 \mathrm{H}_{2} \mathrm{O}$ & 11,76 & - \\
$\mathrm{Mo}$ & 0,1 & $\left(\mathrm{NH}_{4}\right) 6 \mathrm{Mo}_{7} \mathrm{O}_{24} \cdot \mathrm{H}_{2} \mathrm{O}$ & 0,56 & - \\
$\mathrm{Zn}$ & 5,0 & $\mathrm{ZnSO}_{4} \cdot 7 \mathrm{H}_{2} \mathrm{O}$ & 65,2 & - \\
\hline
\end{tabular}

* Adicionados em 21/3/86 - correspondeu ao inicio do primórdio floral 
Após uma homogeneização, a mais uniforme possí vel, a mistura de $3,0 \mathrm{~kg}$ de terra foi transferida para vasos de barro, previamente impermeabilizado com tinta preta neutrox e ägua destilada foi adicionado de modo a manter o nível de umidade pröximo a $80 \%$ da capacidade mäxima de retenção. Fezse o plantio, colocando-se 10 sementes de arroz, cultivar IA 165 em cada vaso. Dez dias após a germinação, foi efetuado o desbaste, deixando 3 plantas. Foram efetuados tratos fitossa nitärios para combater o ataque de pragas, utilizando-se o pi retróide, isento de fósforo, na dosagem de $1 \mathrm{ml} / \mathrm{litro.}$

Aos 60 dias apōs o plantio, o que correspondeu ao inicio do emborrachamento, a parte aērea das plantas foi cortada rente ao solo e acondicionadas em sacos de papel. Em seguida, foram colocadas para secar en estufa de ventila ção forçada a $65-70^{\circ} \mathrm{C}$, durante uma semana, pesadas para obter o peso de matēria seca, e, posteriormente, procedeu-se à determinação do fósforo total no tecido vegetal, de acorcio com metodologia descrita no item 3.5 .

\subsection{Anälise de solos}

As amostras de terra coletadas após a incubação foram, depois de seca ao ar e passadas em peneira de $2 \mathrm{~mm}$ de abertura de malha, submetidas à anälise química para determinação do $\mathrm{pH}$, das formas inorgânicas de fósforo e fósforo solüvel em värios extratores. Os métodos de extraçäo escolhidos foram de 01 sen + EDTA, Mehlich, Resina trocado ra de ànions e Bray-1, os quais são resumidamente descritos a seguir: 
3.4.1. Métodos de extração de fósforo

$$
\begin{aligned}
& \text { 3.4.1.1. Mëtodo de } 01 \text { sen + EDTA } \\
& \text { (MIYAKE et alii, 1984) }
\end{aligned}
$$

Amostras de $4 \mathrm{~g}$ de TFSA foram agitadas por 30 minutos, com $80 \mathrm{ml}$ da solução de $\mathrm{NaHCO}_{3} 0,5 \mathrm{M}$ + EDTA 0,02M ajustada ao pH 8,5 com NaOH IN; filtrou-se a suspensão em papel SES faixa azul. Uma alíquota de $5 \mathrm{ml}$ do filtrado foi transferida para tubo de ensaio de $25 \mathrm{ml}$ e neutraliza da com solução de $\mathrm{H}_{2} \mathrm{SO}_{4} 3 \mathrm{~N}$ gota a gota até o desaparecimento das bolhas de $\mathrm{CO}_{2}$. Após adição de $10 \mathrm{ml}$ do reagente ácido sulfürico-ascōrbico-molibdènio descrito por EMBRAPA (1979), procedeu-se depois de 30 minutos em repouso, à le! tura de absorbância em fotocolorimetro KLETT-SUMMERSON com filtro vermel ho.

3.4.1.2. Método de Mehlich (EMBrapa, 1979)

Agitou-se $10 \mathrm{~g}$ de TFSA por 5 minutos, com $100 \mathrm{ml}$ de $\mathrm{HCl} 0,05 \mathrm{~N} \mathrm{e} \mathrm{H}_{2} \mathrm{SO}_{4} 0,025 \mathrm{~N}$; filtrou-se a suspensão e determinou-se o fósforo colorimetricamente pelo método azul de molibdato da mesma maneira que no caso anterior.

3.4.1.3. Método da Resina (RAIJ e QUAGglo, 1983).

A extração de fósforo por este método foi realizado no Laboratório da Seçäo de Fertilidade do"solo da Escola Superior de Agricultura "Luiz de Queiroz"(ESAlQ). 
Uti lizou-se uma mistura de volumes iguais das resinas trocadoras de ànions (Amberlita: IRA-400, base forte) e cätions (Ambelita |R-120, ácido forte). A mistura de resinas se deve ao fato que a mesma é usada como técnica rotineira de extráção de P, Ca, Mg e K pelo referido laboratōrio. Maiores detalhes são encontrados em. RAIJ e QUAGGIO (1983).

$$
\text { A uma mistura de } 2,5 \mathrm{~cm}^{3} \text { de TFSA e } 25 \mathrm{ml} \text { de }
$$
ägua destilada previamente agitada por 15 minutos, foi ad cionada $2,5 \mathrm{~cm}^{3}$ de resina regenerada. Agitou-se durante 16 horas a 220 rpm, e transferiu-se a suspensão para peneiras com malha de poliester com abertura de $0,4 \mathrm{~mm}$. Depois de lavar a resina com água para retirar a argila, transferiu-se a resina da peneira para um frasco de $100 \mathrm{ml}$. Em seguida, o fösforo adsorvido pela resina foi extraído por $50 \mathrm{ml}$ de uma solução de $\mathrm{NaCl}$ IN e HCl $0, I N$. Depois de deixar ein repouso por $30 \mathrm{minutos,}$ agitou-se por uma hora a 220 rpm, e procedeu-se a determinação do fösforo colorimetricamente, em espectrofotómetro modelo VARIAN, sērie 634, com comprimento de onde $885 \mathrm{~nm}$. A quantidade de ägua adicionada na mistura tem pouco efeito na extração do fósforo.

3.4.1.4. Método de Bray-1 (BRAY e KURTZ, 1945)

Amostras de $7 \mathrm{~g}$ de TFSA foram agitadas por um minuto com $50 \mathrm{ml}$ de soluçæ̃o HCl $0,025 \mathrm{~N}+\mathrm{NH}_{4} \mathrm{~F} 0,03 \mathrm{~N}$ e filtrou-se a suspensão em papel de filtro ses faixa azul. 
o P na solução foi determinado pelo mëtodo azul cioromolib co, usando como redutor o cloreto estanhoso.

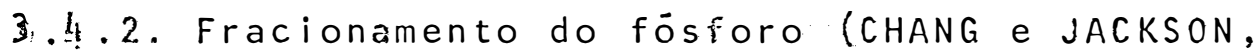
1957)

Para a caracterização das diferentes frações de fösforo inorgânicas, usou-se o método original descrito por CHANG e JACKSON (1957).

o fōsforo inorgânico do solo foi fracionado em $\mathrm{P}-\mathrm{NH}_{4} \mathrm{Cl}$ (solüvel em $\mathrm{NH}_{4} \mathrm{Cl} \mathrm{IN}$ ), $\mathrm{P}-\mathrm{Al}$ (solūvel em $\mathrm{NH}_{4} \mathrm{~F} 0,5 \mathrm{~N}$ neutro), $\mathrm{P}-\mathrm{Fe}$ (solūvel em $\mathrm{NaOH}$ O, IN) e $\mathrm{P}-\mathrm{C} a$ (solūvel em $\left.\mathrm{H}_{2} \mathrm{SO}_{4} \mathrm{O}, 5 \mathrm{~N}\right)$. As fraçōes de $\mathrm{P}-\mathrm{NH}_{4} \mathrm{Cl}$ e $\mathrm{P}-\mathrm{Al}$ foram determinä das pelo método do azuí cloromolibdico e as de P-Fe e P-Ca pelo azul sulfomolibdico. Usou-se o cloreto estanhoso como agente redutor em ambos os casos.

A fração denominada neste trabalho "outros fosfatos" que inclui "p redutível solūvel", "p ocluso" e "fósforo orgânico" foi calculada pela diferença entre p total e a soma das frações inorgânicas mencionadas anterior mente.

\subsection{Análise do material vegetal}

o fósforo na planta foi determinado segundo método sugerido por SARRUGE e HAAG (1974). Amostras de lg 
de planta, seca em estufa a $70^{\circ} \mathrm{C}$ e moídas em Moinho Wiley, malha 20, foram levadas a digestão com ácido nítrico - per clörico na proporção de $20 \mathrm{ml}^{\mathrm{de}} \mathrm{HNO}_{3}$ e $2 \mathrm{ml} \mathrm{HClO}_{4}$. O fósforo foi então determinado por colorimetria usando vanada to-molibdato.

\subsection{Análises estatisticas.}

Com os dados obtidos, foram efetuadas as anälises da variância, segundo o delineamento experimental em blocos casualizados. Para qualificar os efeitos dos tratamentos foi feito a comparação das médias pelo teste de Tukey. Também, foram feitas anälises de regressão e de corre. lação linear simples. 


\section{RESULTADOS E DISCUSSÄO}

\section{1. Formas de fosfatos inorgānicos}

As quantidades de formas de fösforo encontradas nos dois solos em função dos tratamentos foram avalia dos atravēs do fracionamento de CHANG e JACKSON (1957).

Os teores médios das frações inorgânicas de fósforo, obtícos em função dos fatores: fontes de fosfato, tempos de incubação e da interação fontes por tempos, aparecem nas Tabelas 5 e 6 . A anälise de variáncia indica que nos dois solos, existe uma diferença altamente significativa nos diferentes tempos de incubação para todas as frações, com ex ceção das frações $\mathrm{P}-\mathrm{NH}_{4} \mathrm{Cl}$ e $\mathrm{P}-\mathrm{Fe}$ do LVd e LEd, respectivamen te. Quando se empregou o Superfosfato Triplo (SPT), os teores de P-Al diminuiram na medida em que aumentaram os tempos de incubação entre calcārio e fosfato, tanto em LVd como em LEd. Não houve diferença significativa nos teores das fra 
ções $\mathrm{P}-\mathrm{Fe}, \mathrm{P}-\mathrm{Ca}$ e $\mathrm{P}-\mathrm{NH}_{4} \mathrm{Cl}$, com os tempos de incubação entre calcário e SPT em ambos os solos. Os maiores teores de $\mathrm{P}-\mathrm{Al}$ e $\mathrm{P}-\mathrm{Fe}$ e os menores de $\mathrm{P}-\mathrm{NH}_{4} \mathrm{Cl}$ e $\mathrm{P}-\mathrm{Ca}$, foram encontrados nos tratamentos sem calcário.

Quando se empregou o Fosfato de Araxá Parci-

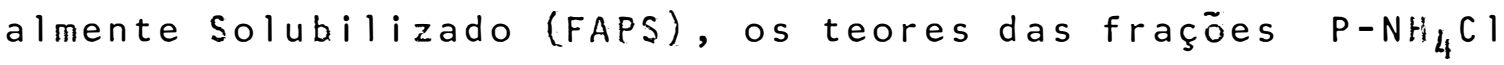
no LEd e P-Al no LVd, aumentaram e diminuiram, respectiva mente, à medida que aumeritaram os tempos de incubação entre calcário e fosfato. As três frações restantes, em cada tipo de solo, não acusaram diferenças significativas com os tempos de incubação entre calcário e FAPS, de forma semelhante ao SPT, os maiores teores de P-Al e P-Fe e os menores de $\mathrm{P}-\mathrm{NH}_{4} \mathrm{Cl}$ e $\mathrm{P}-\mathrm{Ca}$, foram encontrados nos tratamentos sem calcá rio.

0 anteriormente exposto para dos dois fosfatos, indica que existem mudanças nos teores das frações inorgânicas de fósforo com os tempos de incubação, em am*bos os solos (Tabelas 5 e 6 ). 0 que possivelmente foi causa do pelos aumentos nos valores de $\mathrm{pH}$, devido ao maior tempo de contato entre calcário e fonte de fosfato, conforme foi demonstrado na Tabela 11.

A elevação do pH possibilita maior formação de fósforo mais facilmente aproveitável, isto é, $P-\mathrm{NH}_{4} \mathrm{Cl}$ e P-Ca. Segundo CABALA e FASSBENDER (1971) e BRAGA e DEFELIPO (1972a), a calagem afeta as formas de fósforo inorgânico do 


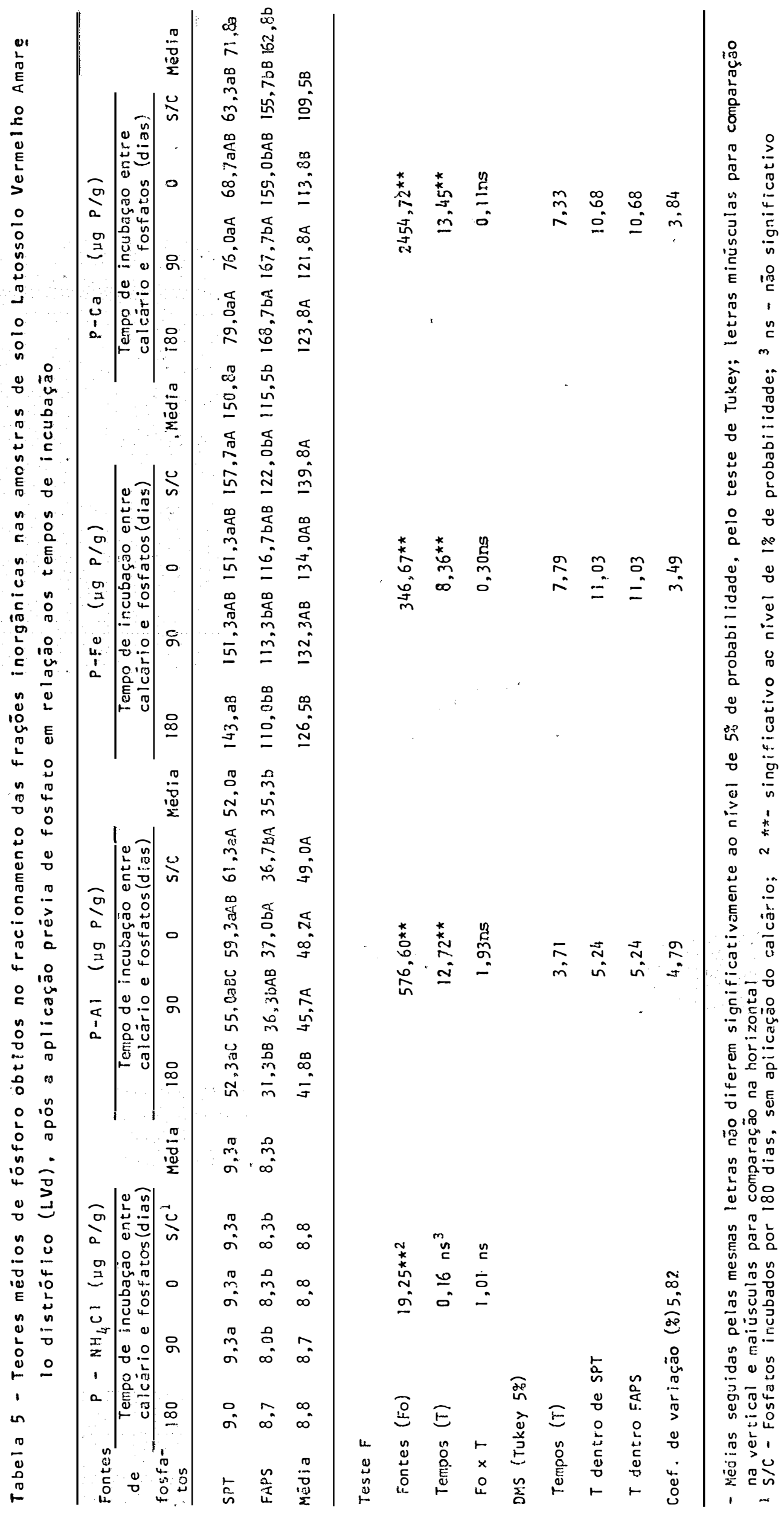




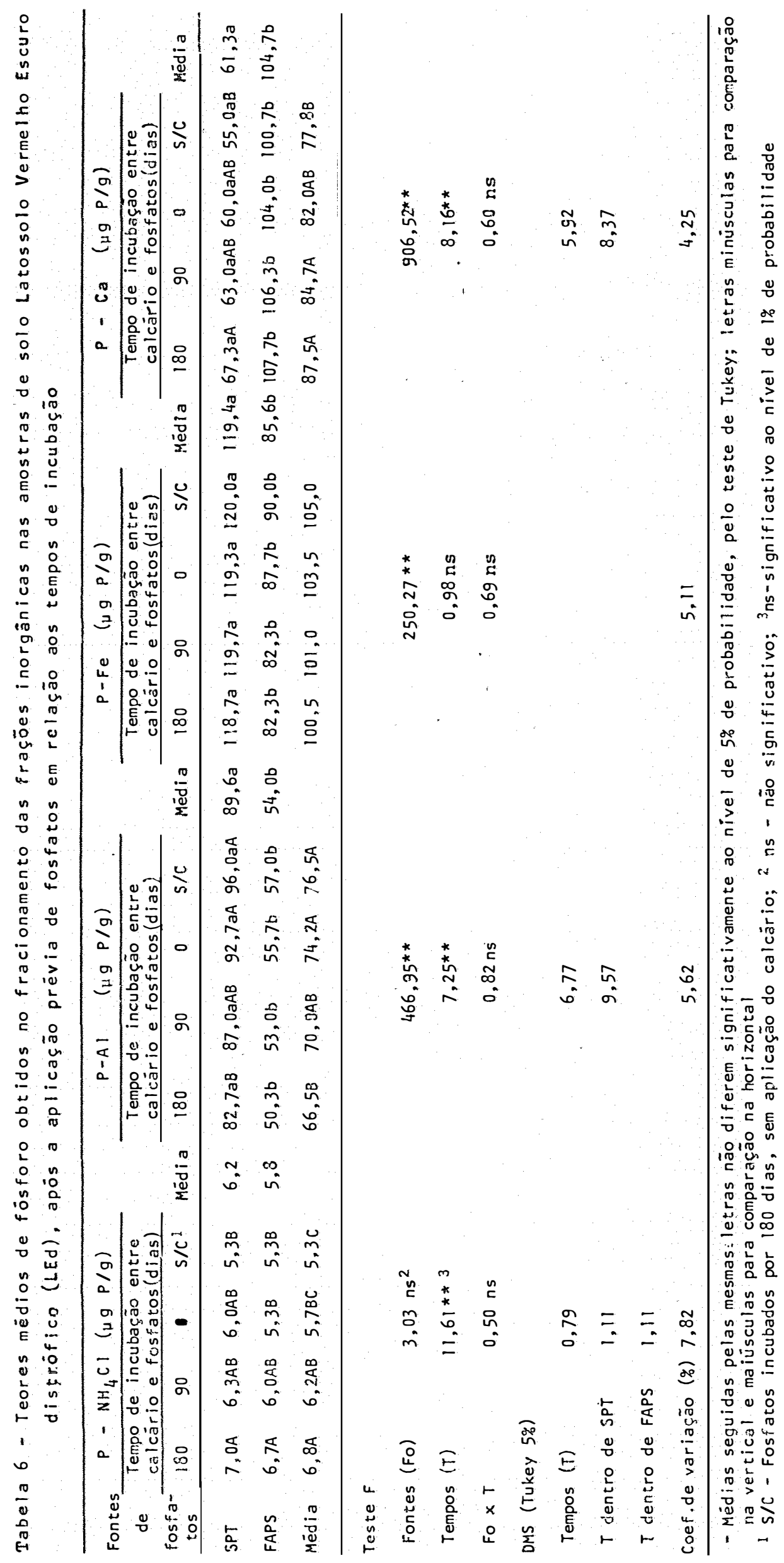


do solo, muito embora esta alteração não seja uniforme para todos os solos. 0 que se confirma ao observar que os tratamentos com calcário no LVd, aumentaram os teores de P-Ca, não alteraram os de $\mathrm{P}-\mathrm{NH}_{4} \mathrm{Cl}$ e reduziram os de P-Al e P Fe em: relação aos tratamentos sem calcário. Já no LEd a tendência foi a de aumentar os teores de $\mathrm{P}-\mathrm{NH}_{4} \mathrm{Cl}$ e $\mathrm{P}-\mathrm{Ca}$, não alterar os de P-Fe e reduzir os de P-Al. A diminuição dos teores de P-Al e P-Fe; possivelmente foi devido à eleva ção do pH pela calagem, condição que desfavorece a formação de variscita e estrengita, fato admitido por BRAGA e DEFELIPO (1972a).

A adição de fósforo aos solos, atravēs de duas formas de compostos fosfatados, alterou significativamente os teores das diferentes frações de fósforo conforme se vê nas Tabelas 5 e 6. Quando a fonte adicionada foi o SPT, os teores das frações $P-N_{4} C l, P-A l$ e $P-F e$ foram signi ficativamente maiores do que quando se empregou o fosfato de Araxá Parcialmente Solubilizado (FAPS), tanto no LVd como no LEd. Explica-se esse comportamento em face da maior quantidade de fosfato monocálcico presente no SPT do que no FAPS, que em condição äcida transforma-se em fosfato de fer ro e alumínio dada a alta atividade desses cátions. Segundo LINDSAY et alî (1962), HSU (1965) e PARFITT et alii (1975), os produtos de reação de fertilizantes fosfatados com o solo dependem, sobretudo das condições de acidez. durante a dissolução do fertilizante. No caso do superfosfato, o fos- 
fato monocálcico se dissolve em $\mathrm{H}_{2} \mathrm{O}$ com consequente formação de $\mathrm{H}_{3} \mathrm{PO}_{4}$ que ao reagir com $\mathrm{Fe}$ e Al existentes na solu ção do solo, formam fosfatos de baixa solubilidade como fosfatos de ferro e alumínio.

Com relação à fração P-Ca nota-se que os solos adubados com FAPS possuem mailifósforo nessa forma que as com SPT. Isto é compreendido pelo fato de que o FAPS por ser um fosfato natural parcialmente solubilizado, apresenta na sua composíção uma proporção maior de fósforo na forma de fosfato tricālcico de baixa solubilidade. Resultado semelhante foi encontrado por GOEDERT et alii (1971), em parcelas adubadas com fosfatos naturais e fosfatos soluveis. Não houve efeito da interação entre fontes e tempos de incubação, para todas as frações inorgãnicas em ambos os solos

$$
\text { Os teores das fraçöes P-Fe, P-Al e P-NH }{ }_{4} \mathrm{Cl} \text {, }
$$
foram significativamente maiores quando se empregou o SPT do que quando se usou o FAPS em qualquer tempo de incubação e para ambos os tipos de solos. Acontecendo o contrário quando se considerou os teores de P-Ca; o que está de acordo com a explicação anterior de que o FAPS apresenta na sua composição uma proporção maior de fösforo na forma de fosfa to tricálcico, que ainda não reagiu com o solo, o que confirma o sugerido por BAHIA FiLHO et alii (1982).

Na Tabela 7 são mostrados os teores mëdios 


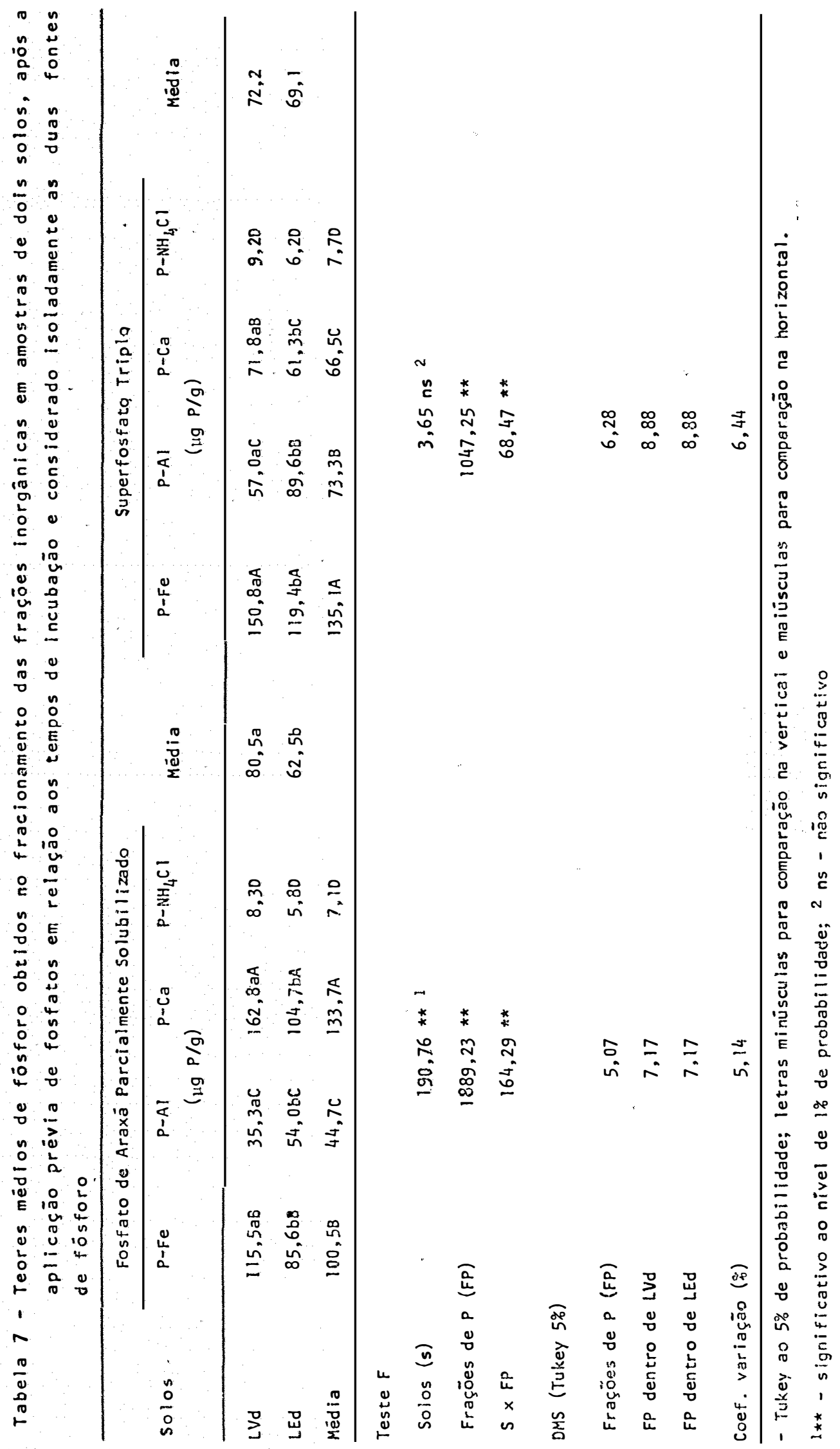


das frações inorgânicas de fósforo, considerando por separado as duas fontes de fósforo em função dos fatores: solos, formas de fósforo e da interação solos por formas de P quando foi significativa. Para as duas fontes de fósforo, observa-se um efeito altamente significativo para todos os fatores. Quando se considerou o FAPS, os teores médios das frações decresceram na seguinte ordem: $\mathrm{P}-\mathrm{Ca}>\mathrm{P}-\mathrm{Fe}>$ $\mathrm{P}-\mathrm{Al}>\mathrm{P}-\mathrm{NH}_{4} \mathrm{Cl}$. Isto confirma ainda mais do que o FAPS apresenta na sua composição uma proporção maior de fósforo na forma de fosfatos tricālcico, que ainda não reagiu com o solo.

Considerando o SPT, observa-se que os teores médios das frações variaram na ordem seguinte: P-Fe> $\mathrm{P}-\mathrm{Al}>\mathrm{P}-\mathrm{Ca}>\mathrm{P}-\mathrm{NH}_{4} \mathrm{Cl}$. Confirmando esse comportamento em face da maior quantidade de fosfato monocälcico presente no SPT do que no FAPS, que em condição àcida transforma-se em fosfato de ferro e alumínio dada à alta atividade desses cátions (LANDSAY èt alîi, 1962).

Os teores médios das fraçöes inorgânicas: P-Fe, $\mathrm{P}-\mathrm{Ca}$ e $\mathrm{P}-\mathrm{NH}_{4} \mathrm{Cl}$ em ambas as fontes de fösforo, foram maiores no LVd que no L.Ed; indicando uma maior fixação de fósforo nessas formas por parte do LVd.

\subsection{Fösforo "disponivei"}

o fośforo "disponivel" obtido nos dois so- 
los pelos extratorøs utilizados è apresentado nas Tabelas 8 e 9. Dependendo do solo, fonte de fósforo e tempos de incubação, os teores obtidos variaram de 16,5 a $69,4 \mu \mathrm{g} / \mathrm{g}$ para o extrator Mehlich, de 12,9 a $32,8 \mu g$ P/g para o de Bray-1, de 21,6 a $37,1 \mu g$ P/g para o de Olsen + EDTA e de 15,6 a $39,6 \mathrm{~g} P / \mathrm{cm}^{3}$ para o da Resina trocadora de ânions. Colocando os extratores em ambos os solos, em função da quan tidade de fósforo extraído, ficaria a seguinte sequência no SPT: 01 sen = Resina e Bray-1 > Mehlich, enquanto que na FAPS a ordem encontrada foi a seguinte: Mehlich>0lsen> Resina > Bray-1.

Nas Tabelas 8 e 9 aparecem os teores médios de fósforo "disponivel", obtidos em função dos fatores prin cipais e da interação fontes de fósforo por tempos de incubação quando foram significativas, quanto aos diferentes tempos de incubação, observa-se no LEd efeitos altamente significativos nos extratoras: Mehlich, Olsen e Resina. No caso do LVd, este efeito foi evidente somente para o extrator Resina, indicando dentro de certos limites que existem variações nos teores de fósforo "disponível", dependendodos tempos de incubação e do extrator usado em ambos os solos.

A anälise de variância dos teores de fósforo "disponível" evidencia tambēm, que a aplicação dos fosfatos em ambos os solos alterou de maneira diferente as concentrações de fósforo dependendo do extrator usado. Quando ë usado o SPT, hä um aumento significativo na quantidade de 
fósforo "disponivel" extraido pelos" extratores Bray-1, 0,sen + EDTA e Resina, em comparação com o FAPS (Tabelas 8 e 9). Os teores do fósforo "disponivel" diminuiram com a aplicação do SPT em relação ao FAPS, quando o extrator foi o Mehlich, mostrando que este extrator dissolve minerais de apatita não tratados com ácido durante o processo de ob tenção do FAPS, o que permaneceu sem reação no solo. Isto indica a inadequação da extração por Mehlich quando o FAPS é usado nestes solos. Esta limitação do extrator Mehlich tem sido relatada por vários pesquisadores (FEITOSA e RAIJ, 1976; GOEDERT e LOBATO, 1980; RAIJ et alii, 1982; BAHIA FILHO, 1982; CABALA e SANTANA, 1983a).

Houve interações significativas entre fontes de fósforo e tempos de incubação em ambos os soios. Com relação ao fósforo extraído pelos extratores Bray-l e Mehlich, observou-se que os teores de fósforo "disponivel" dentro do SPT não variaram significativamente na medida que aumentaram os tempos de incubação entre calcārio e fosfato em ambos os solos. Ainda em relação ao Bray-l e Mehlich, observou-se que o SPT na presença de calcärio forneceu teo res mais altos de fósforo "disponível" que na ausencia de calcário, o que era de se esperar, já que houve aumentos nos valores de pH pela aplicação do calcārio, como se observa na Tabela 11. Já quando se adicionou o fAPS e com relação ao fósforo extraído pelo extrator Mehlich, obtevese aumentos nos teores de fósforo "disponivel" no LVd, na 
medida que diminuiram os tempos de incubação entre calcärio e FAPS, o que era esperado, devido a menores valores de pH nos referidos tempos. Para o extrator Bray-1, em ambos os solos, como para o Mehlich no LEd, não se encontraram diferenças significativas nos teores de fósforo "dispo nível" através dos tempos de incubação entre calcārio e FAPS; os maiores teores de fósforo "disponível" foram encontrados na ausência de calcário. Isto canacteriza o efei to favorável da acidez do solo na dissolução do fosfato parcialmente acidulado, algo similar ao que acontece com os fosfatos nacurais. Este fato é compreensível, considerando-se que parte da composição dos fosfatos parcialmente acidulados permanece como rocha fosfatada e, como tal, se decompõe em meio àcido para formar fosfato monocálcico e outros compostos solúveis. GOEDERT e LOBATO (1980) verificaram que, aumentando o $\mathrm{pH}$ de 4,8 a 5,9 através de calagem, a eficiência do fosfato Patos diminuiu e o de Superfosfato triplo aumentou, em termos de produção de soja.

No caso do extrator 01 sen + EDTA houve também uma interação altamente significativa entre as fontes de fösforo e os diferentes tempos de incubação em ambos os solos. Dentro dos tratamentos com SPT e considerando o LVd, pode-se observar que os maiores teores de fösforo"dis ponivel" ocorreram na medida que aumentaram os tempos de incubação entre calcārio e fosfato. O que era de se espe- 


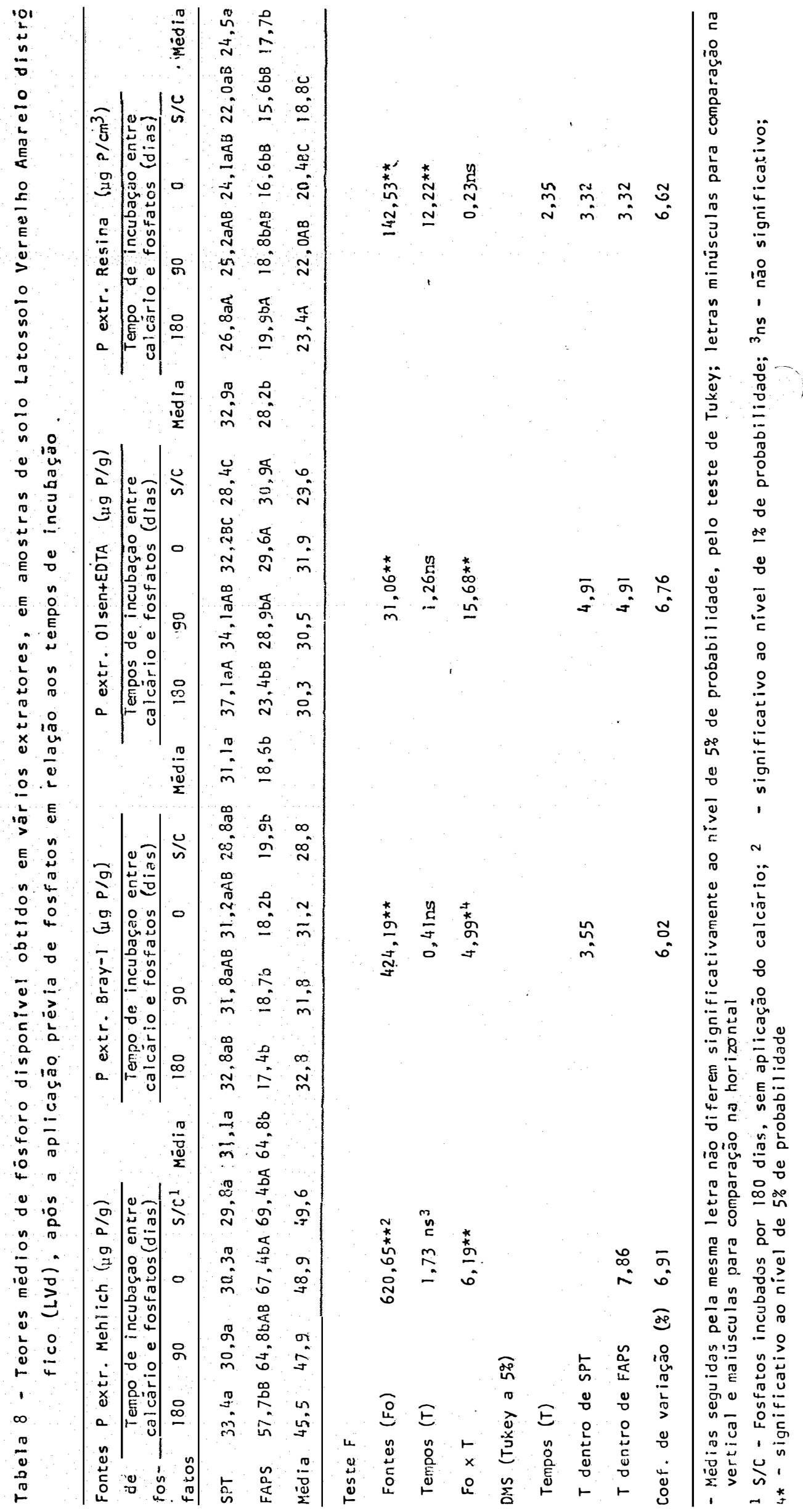




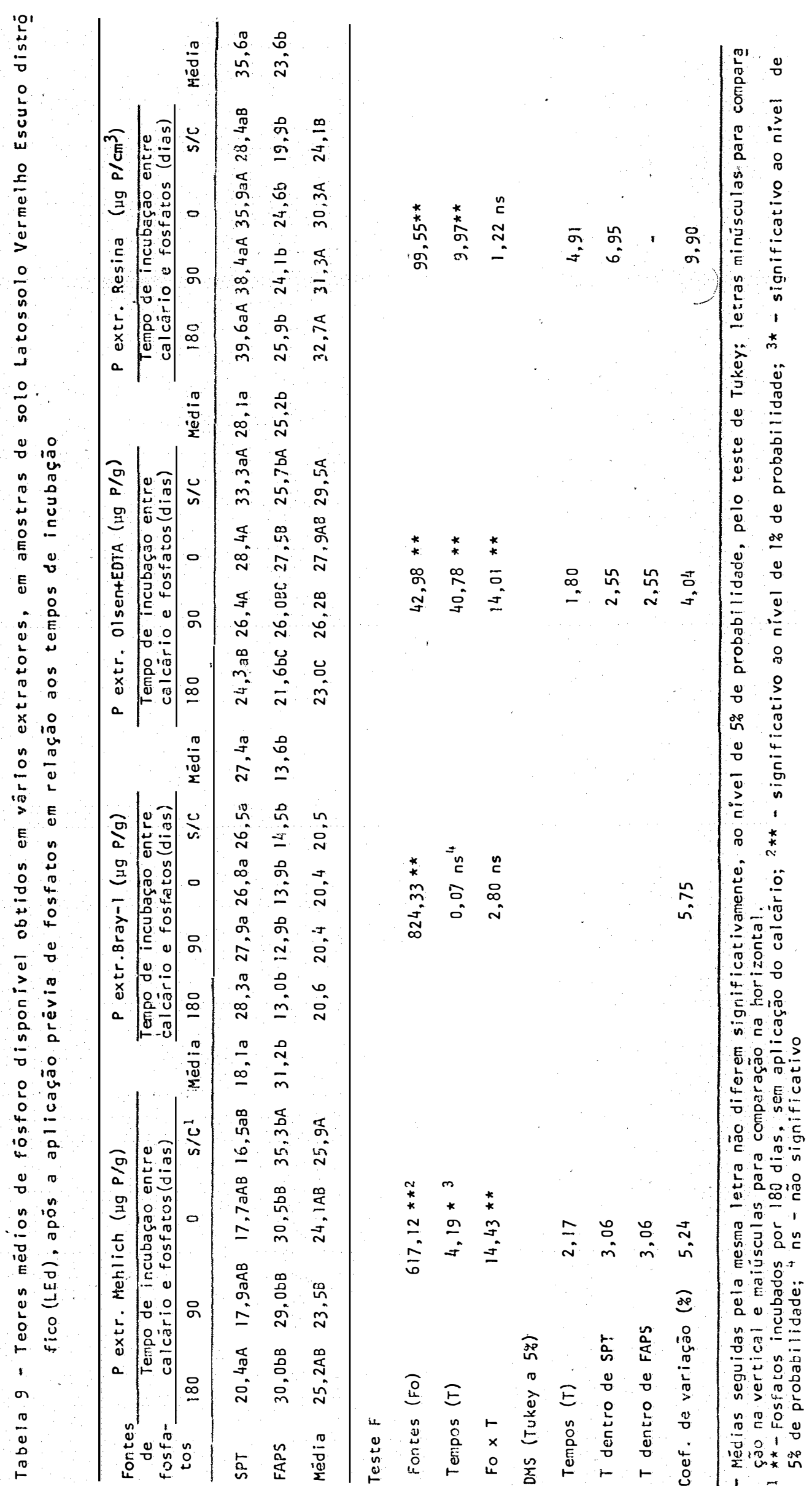


rar, devido aos aumentos de pH nos refericios tempos, como se observa na Tabela 11, fato jä comprovado ao se compa rar os teores na presença dé calcärio, com os obtidos na ausência de calcário. Dentro dos tratamentos com FAPS, a tendência foi de aumentar os teores de fösforo "disponí vel" na medida que diminuem os tempos de incubação entre calcārio e fosfato (Tabela 8), o que era esperado, devido a menores valores de pH. Caracterizando dessa. forma o efeito favorável da acidez do solo na dissolução do FAPS.

$$
\text { Em relação ao } 01 \text { sen + EDTA, e quando se }
$$
considera o LEd dentro do SPT, observa-se que esta interação obedece a uma sequência diferente neste tipo de solo (Tabela 9). BRAGA e DEFELIPO (1972a) tambëm encontra ram uma diminuiçäo do fósforo "disponível" quando o extrator foi o olsen + EDTA, segundo os autores, provaveimente houve enfraquecimento do poder extrativo dos reagentes, devido à calagem. Ainda em relação ao olsen + EDTA e Bray-1, os teores obtidos com FAPS foram mais baixos. comparados ao SPT. nos diferentes tempos. Istoocorre por que o extrator 01 sen e Bray-l têm sua extração baseada na hidrölise de fosfatos de Al ou Fe, não removendo fosfatos de cälcio, conforme reconhecem Kamprath e Watson (1980) e Thomas e Peaslee (1973), citados por BAHIA FILHO er alii (1982). 
Quando se adicionou SPT em ambos os solos, os teores de fósforo "disponível" extraídos pela Resina, não acusaram diferenças sigńificativas com os tempos de incubação entre calcário e fosfatos. Os maiores teores de fósforo ocorreram na presença de calcärio (Tabeias 8 e 9). Quando o FAPS foi adicionado houve aumentos significativos nos teores de fósforo no LVd na medida que aumentaram os tempos de incubação entre calcário e foosfato. Já dentró do LEd, o efeito do FAPS não foi significativo nos diferentes tempos.

Na Tabela 10, são mostrados os teores médios de fósforo "disponível", considerando por separado as duas fontes de fósforo em função dos fatores: solos, extrato res e da interação extratores por solos. Para as duas fontes de fósforo, observa-se efeitos significativos para todos os fatores. Quando se considera o FAPS, os teores médios de fósforo "disponível" variaram na seguinte ordeni: P-Mehlich $=48,0 \mu g P / g, P-01$ sen $=26,7 \mu \mathrm{gP} / \mathrm{g} ; \quad \mathrm{P}$-Resina $=$ $20,7 \mu \mathrm{g} \mathrm{P} / \mathrm{cm}^{3}$ e $\mathrm{P}-\mathrm{Bray}-\mathrm{l}=16,1 \mu \mathrm{g} P / \mathrm{g}$. 0 que indica que o extrator Mehlich dissolve minerais de apatita não tratados com ácido durante o processo de obtenção do FAPS, o que permaneceu sem reação no solo; mostrando a inadequação do Mehlich quando o FAPS è usado nestes solos. Fato já demonstrado por FEITOSA e RAIJ (1976). Ainda dentro do FAPS e con siderando o LVd, observou-se que a ação extratora da Resina foi reduzida em comparação aos extratores químicos Mehlich e 01 sen + EDTA, o fósforo extraído pela Resina trocadora de 


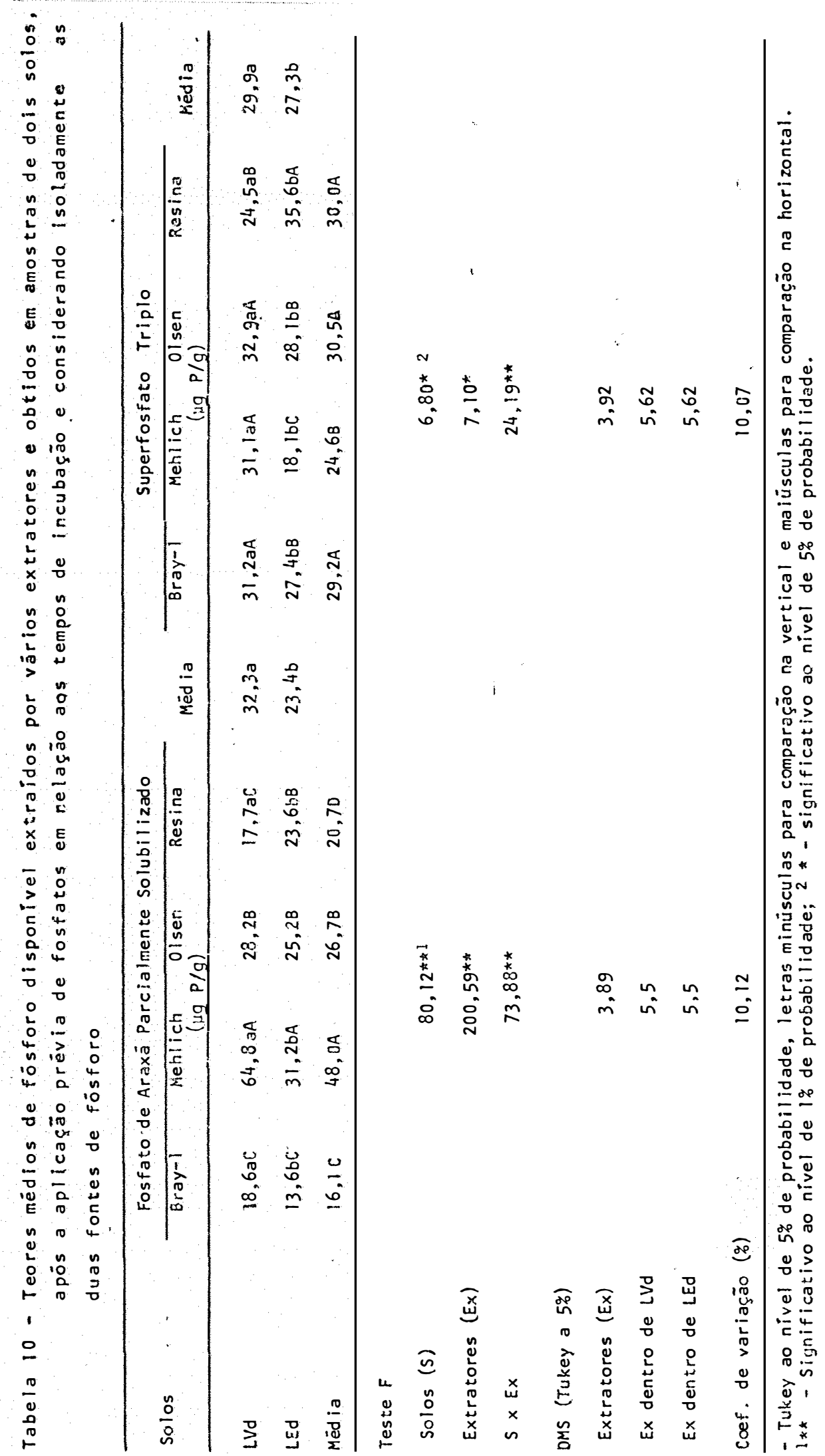




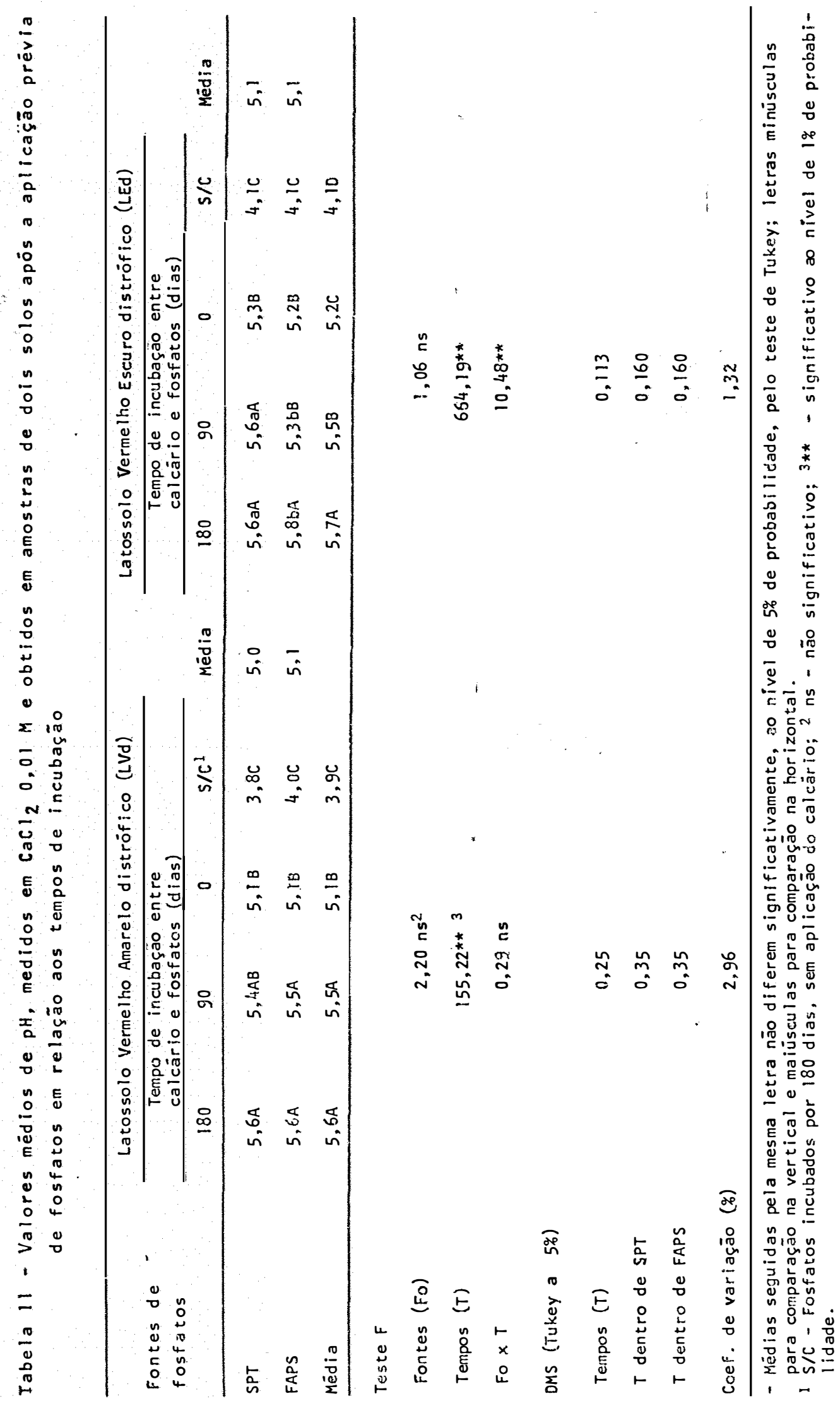


íons representa a extração do elemento da fração läbil, en quanto que os extratores quimicos extraem fósforo tanto da fração lábil quanto da fração não läbil, conforme menciónam diversos autores: BAHIA FILHO e BRAGA (1975), NOVELINO et alii (1985) e H!SLOP e COOKE (1966).

Com a adição do SPT, encontrou-se a seguinte ordem nos teores mëdios de fósforo "disponível" dos värios extratores: P-0lsen+EDTA $=30,5 \mu \mathrm{g} / \mathrm{g}, \quad \mathrm{P}-$ Resina = $30,0 \mu \mathrm{gP} / \mathrm{cm}^{3}, \quad \mathrm{P}-\mathrm{Bray}-1=29,2 \mu \mathrm{g} P / \mathrm{g}$ e P-Mehlich $=24,6$ ug P/g. Dentro de cada solo e com SPT as variações foram diferentes. Assim no LEd a sequência encontrada foi a seguinte: $P$-Resina $>P-01$ sen $=P-$ Bray-l $>$ P-Mehlich. Já no LVd, os teores de fósforo "disponivel" nos värios extrato res, estiveram próximos de $30 \mu \mathrm{g} \mathrm{P} / \mathrm{g}$.

observando-se os teores de fósforo "disponível" da Tábela 10 para o LEd, pode-se verificar que os valores obtidos principalmente com os extratores Bray-l, $01 s e n+E D T A$ e Mehlich, são inferiores aos obtidos pelos mesmos extratores para o LVd. Uma das causas dos baixos teores de P-"disponivel" no LEd pode ser a quantidade Ide argila maior desse solo (Tabela 1). PRATT e GARBER (1964) mostraram num trabalho realizado com värios solos da California, que em solos com maior teor de argila diminuiu a eficiência dos extratores Bray-l e olsen em extrair fös foro. Segundo os autores, a menor eficiéncia desses extra tores para extrair fósforo de solos argilosos está relacio 
nada a reações secundärias após a dissolução ou ainda com a exaustão dos reagentes devido a sua reação com outros mi nerais do solo que não sejam fosfatos. Este efeito da textura refere-se a eficiencia dos extratores para extrair fósforo e não sobre a disponibilidade de fósforo para as plantas, embora os dois efeitos podem estar interrelaciona dos.

Os efeitos dos tempos de incubação, sobre os valores de pH, são vistos na Tabela ll. Como se observa o pH foi afetado dentro de cada fonte de fosfato nos diferentes tempos de incubação. 0 que indica dentro de limites que o pH aumentou com os tempos de contato entre calcạ rio e adubo, os menores valores de pH em ambos os solos, foram encontrados nos tratamentos sem calcário; não houve tendência dos fosfatos de alterar os valores de $\mathrm{pH}$, tanto em LVd como em LEd.

\subsection{Relaçoes entre fösforo "disponivel" e fraçöes inorgânicas de fóstoro}

os teores de fösforo "disponivel" obtidos atravès dos diversos extratores foram correlacionados entre si e os coeficientes de correlação linear são mostra dos na Tabera 12. Nas amostras com calagem e considerando o superfosfato triplo, observou-se uma correlação positiva entre o fósforo do solo extraído pelo extrator Mehlich e 
Tabela 12 - Coeficientes de correlaçäo linear entre teo res de fósforo "disponível" obtidos por extratores em amostras de dois solos incubados em diferentes tempos, considerando as fontes e a calagem

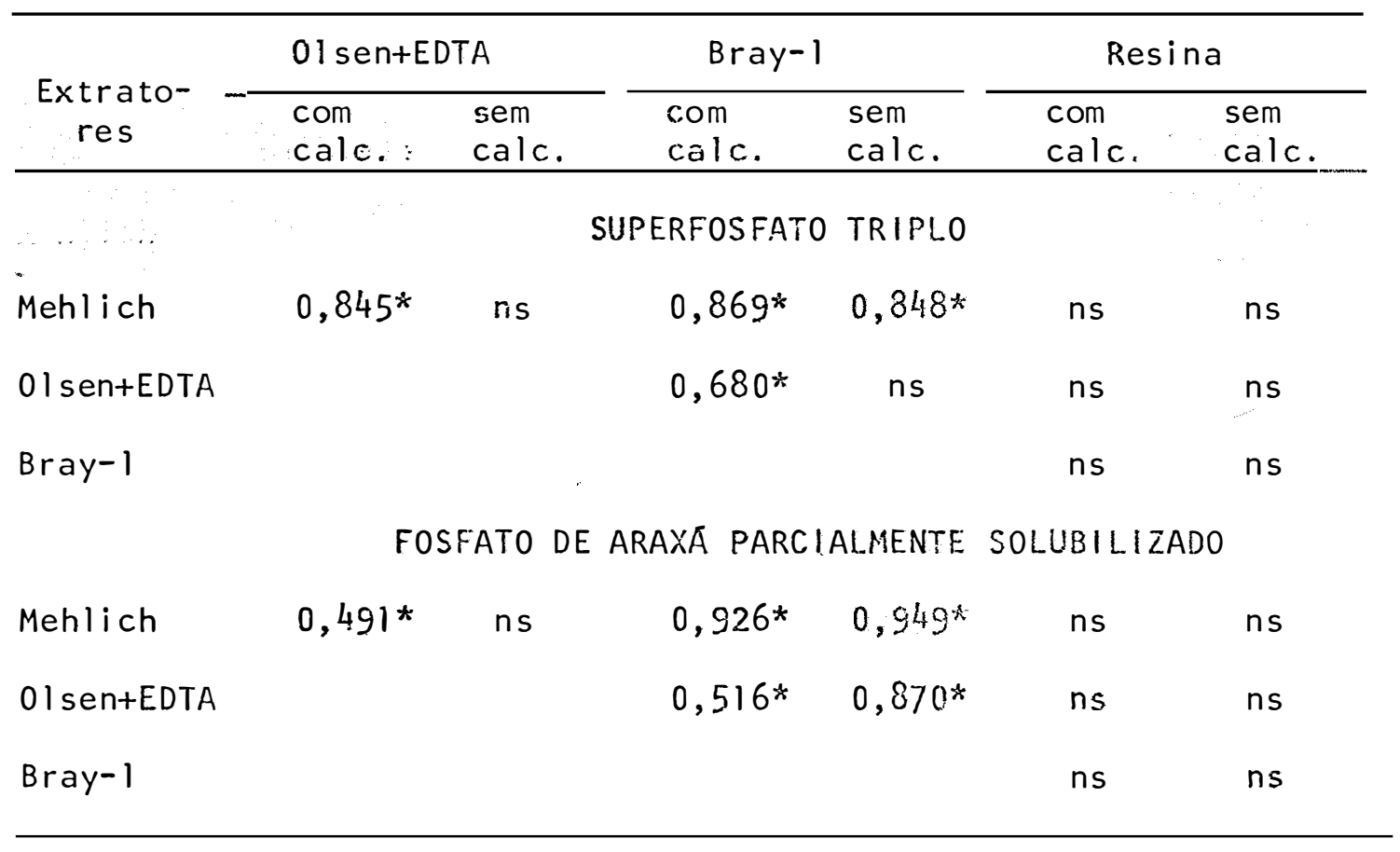

* Significativo ao nivel de $5 \%$ de probabilidade. ns - Não significativo

0lsen+EDTA, Mehlich e Bray-l e 0lsen e Bray-l. Nas amostras sem calagem, somente os teores de fósforo obtidos com Mehlich correlacionaram significativamente com os teores de fósforo usando o Bray-l. Ain da nas amostras sem calagem não se constatou correlação entre os teores de fósforo extraídos com 0lsen + EDTA com os demais extratores estudados. Supõe-se que a ausência de calagem esteja diminuindo a eficiència do método de olsen t EDTA na extração de fósforo "disponivel". Isto po- 
de estar relacionado à exaustão dos reagentes e precipitações secundārias.

os teores de fósforo extraídos pelo extrator Resina, não se correlacionaram com os teores de fósforo obtidos com os demais extratores. Possivelmente porque a Resina não extraiu as mesmas formás de fósforo extraídos pelos métodos Mehlich, Bray-l e 01 sen + EDTA. Segundo BAHIA FILHO e BRAGA (1975) e BAHIA FILHO et alii (1982), coeficientes altos e coincidentes para certos extratores significam que estes extratores estão extraindo as mesmas formas de fósforo. Assim, observando-se a Tabela 13, constatou-se no superfosfato triplo que as formas predominante mente extraidas pelos mētodos Mehlich e Bray-l foram $\mathrm{P}_{-} \mathrm{NH}_{4} \mathrm{Cl}$ e P-Fe, tanto nas amostras sem e com calagem. A maior dissolução da forma de P-Fe nos extratores Mehlich e Bray1, provavelmente, esteja relacionada com a predominância desta forma ou, ainda, com sua maior solubilidade em relação aos fosfatos de alumínio e cálcio, através dos íons $\mathrm{H}^{+}$ dos ácidos sobre o ferro. BARBER e AL-ABBAS (1964) verificaram que a forma P-Fe explicava a variabilidade do fósforo no solo e, por isso, recomendaram um método químico com tendência de dissolução seletiva para fosfatos ligados ao ferro. KHANNA (1967) obteve alta correlação positiva entre - extrator Bray-l e as formas $\mathrm{P}-\mathrm{NH}_{4} \mathrm{Cl}$ e $\mathrm{P}-\mathrm{Fe}$, e negativa para $P-C a$ e nenhuma correlação com P-Al. Também BRAGA e DEFELIPO (1972a) trabalhando em solos sem e com calagem, 


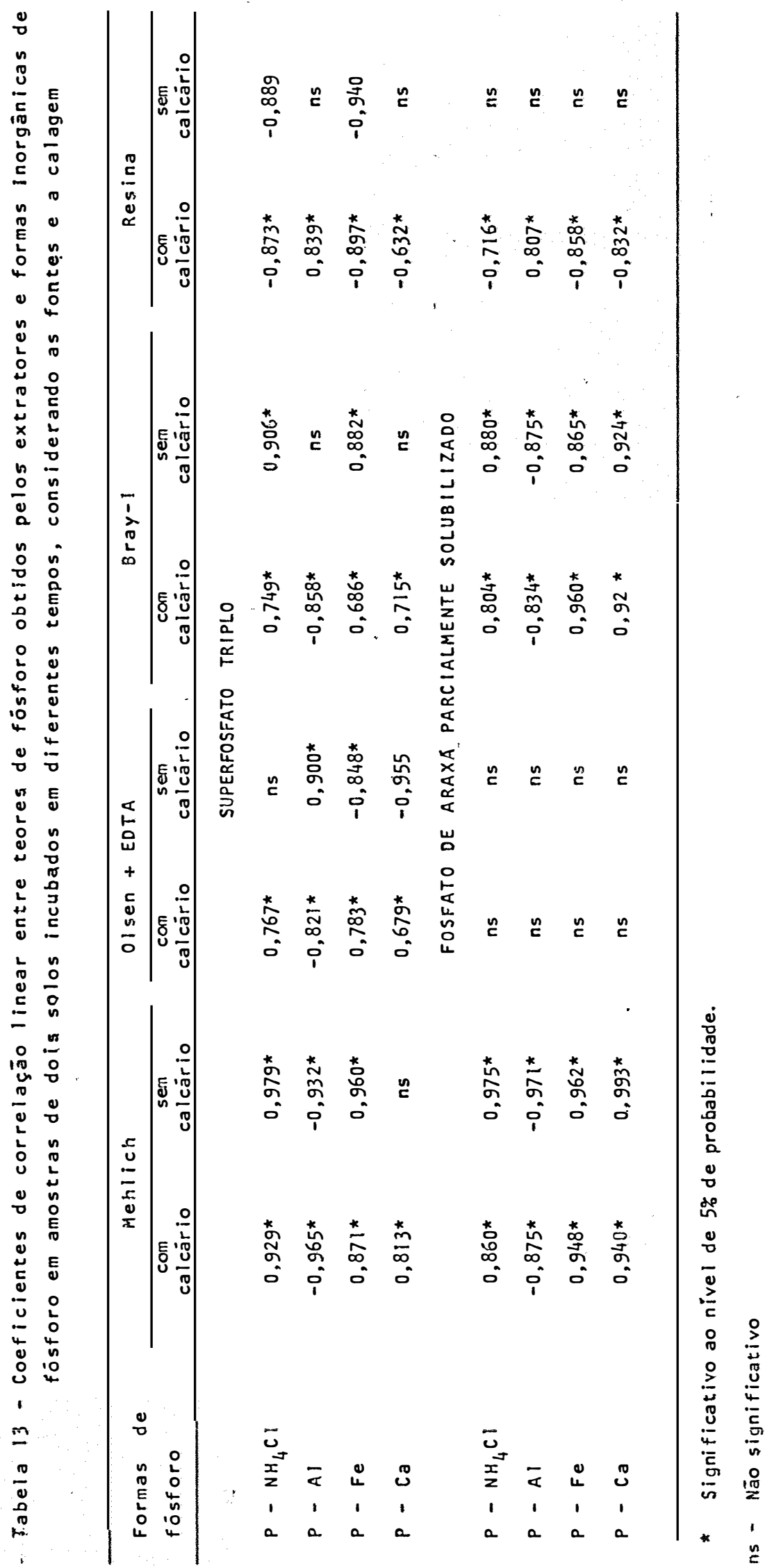


obtiveram resultados semelhantes em amostras de solo com cal agem.

Em relação ao extrator Resina e ainda dentro do SPT, a forma preferencialmente extraida nas amostras com calagem foi $P-A l$, o que explica a inexistência de correlação significativa deste extrator com os demais. A forma de P-Ca correlacionou somente nas amostras com calagem, com os teores de fósforo "disponivel" dos extratores Mehlich, Bray-l e 01 sen + EDTA. As formas extraídas pelo extrator 0lsen + EDTA nas amostras com calcärio foram os de $\mathrm{P}-\mathrm{NH}_{4} \mathrm{Cl}, \mathrm{P}-\mathrm{Fe}$ e $\mathrm{P}-\mathrm{Ca}$.

Quando foi adicionado o Fosfato de Araxá Parcialmente Solubilizado (FAPS), os teores de fósforo obtidos com Mehlich, Bray-l e 0lsen + EDTA correlacionaram entre si, tanto na presença como na auséncia de calcārio, exceção feita somente quando se relaciona o Mehlich e 01sen sem calcārio. Para o mētodo da Resina não se observou correlações significativas com os métodos anteriormente mencionados (Tabela 12). As formas predominantemente extraI das pelos extratores Bray-l e Mehlich, foram $\mathrm{P}-\mathrm{NH}_{4} \mathrm{Cl}, \mathrm{P}-\mathrm{Fe}$ e P-Ca, como mostram os coeficientes de correlação linear da Tabela 13. Embora não houve significância para 0lsen + EDTA, as correlações altas verificadas em Mehlich e Bray-l, com a forma $\mathrm{P}-\mathrm{Ca}$, se deve à presença de fosfato tricálcico na composição do FAPS, o qual contribuiu para uma maior pro 
porção desta fração no solo (Tabelas 5 e 6 ).

De acordo com HISLOP e COOKE (1966), a técnica de extração de fósforo pela Resina reflete ambos os fatores capacidade e intensidade (fração lábill) de fósforo no solo e os extratores quimicos mais frequentemente usados representam em grande parte, o fator quantidade (frạ ção lábil mais a não lábill). o que explicaria possivelmente a inexistência de correlações significativas entre os extratores químicos e a Resina trocadora de ânions.

\subsection{Resposta do arroz aos fatores estudados}

Nas Tabelas 14 e 15 são apresentados, respectivamente, para LVd e LEd, as médias dos rendimentos de matēria seca, concentrações de fósforo e fósforo acumulado na parte aérea do arroz obtidas nos diversas tratamen tos.

Considerando os efeitos das fontes de fósfo ro, constatou-se pela anălise de variância que, para os dois solos e a exceção da variāvel concentração de fósforo para O LEd; O SPT forneceu valores significativamente mais elevados em relação ao FAPS. Outros autores têm demonstrado também comportamento inferior do FAPS em relação ao SPT, quanto à produção de matéria seca e fósforo absorvido por värias culturas (NAKAYAMA, 1982; BARBOSA FILHO et alii, 1983 e NOVAES et alii, 1983. 
Quando se estudou o fósforo "disponivel" antes do plantio do arroz, pelo extrator Mehlich (Tabelas 8 e 9), observou-se que para os dois solos, valores mais altos foram obtidos nos tratamentos com FAPS, confirmando o fato de que esse extrator dissolve compostos fosfatados no solo não disponiveis para as plantas. Mesmo assim existirão rela ções positivas entre teores de fósforo obtidos com Mehlich e as variáveis, produção de matéria seca e fósforo acumulado na parte aérea (Tabela 16). Isto se deveu aos teores de fósforo "disponivel" fornecidos pelos tratamentos com SPT e não com FAPS, como mostra com mais clareza as relações de matéria seca e fósforo acumulado na parte aérea, donde os teores mais elevados de fósforo "disponivel" fornecidos pelo FAPS no extrator Mehlich, resultaram em menores produções de mátéria seca e acumulações de fósforo pela parte aérea do arroz, tanto em LVd como em LEd (Tabelas 14 e 15).

A anālise de variancia dos dados indicou que houve uma interação altamente significativa entre fontes e tempos de incubação, com relação à produção de matéria seca e fósforo acumulado (Tabela 15). O desdobramento da interação para produção de matéria seca mostrou significância para ambas as fontes de fósforo. Dentro de limites e considerando o SPT, na medida que aumentou o tempo de incubação entre calcário e fosfato, subiu também a produção de matéria seca. O que era esperado jä que houve aumentos nos valores de pH com os tempos de incubação (Tabela ll), a me 
nor produção de matēria seca foi obtida no tratamento sem calcārio.

Quando se adicionou o FAPS, notou-se uma tendência em diminuir a produção de matēria seca na medida que aumentaram os tempos de incubação entre calcārio e adubo, embora este efeito foi significativo no LEd (Tabela 15), também o LVd mostrou efeito parecido (Tabela 14). Isto se deve possivelmente aos aumentos de pH sofridos na medida em que aumentaram os tempos de incubação entre cal cārio e fosfato; a produção de matēria seca foi maior no tratamento sem calcārio. Em relação ao FAPS, o resultado obtido neste trabalho está de acordo com as afirmações de FREIRE et alii (1983), segundo os quais a calagem prejudi cou a eficiência dos fosfatos parcialmente acidulados em termos de produção de matēria seca de sorgo, pelo que se obtēm na literatura, que a calagem diminui a eficiên cia dos fosfatos naturais e parcialmente acidulados conforme resultados obtidos por GOEDERT e LOBATO (1982) e ASHBY et alii (1966).

No referente a fósforo acumulado na parte aērea do arroz observa-se que houve uma interação altamente significativa entre fontes de fósforo e tempos de incubação no LEd. Ao fazer o desdobramento, verificou-se significância somente para o SPT em ambos os tipos de solos (Tabelas 14 e 15). Vê-se pelas tabelas que os tempos de 


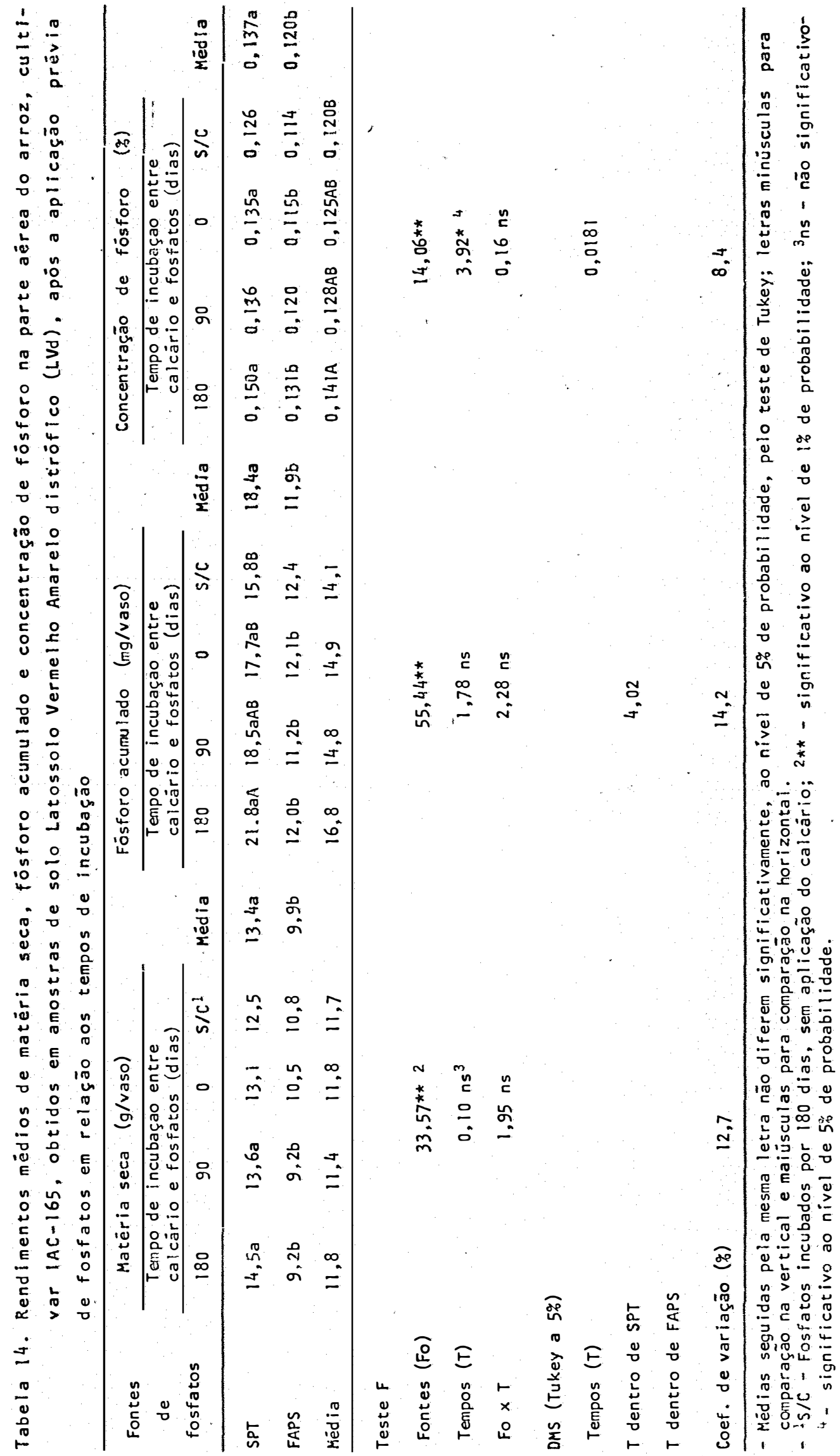




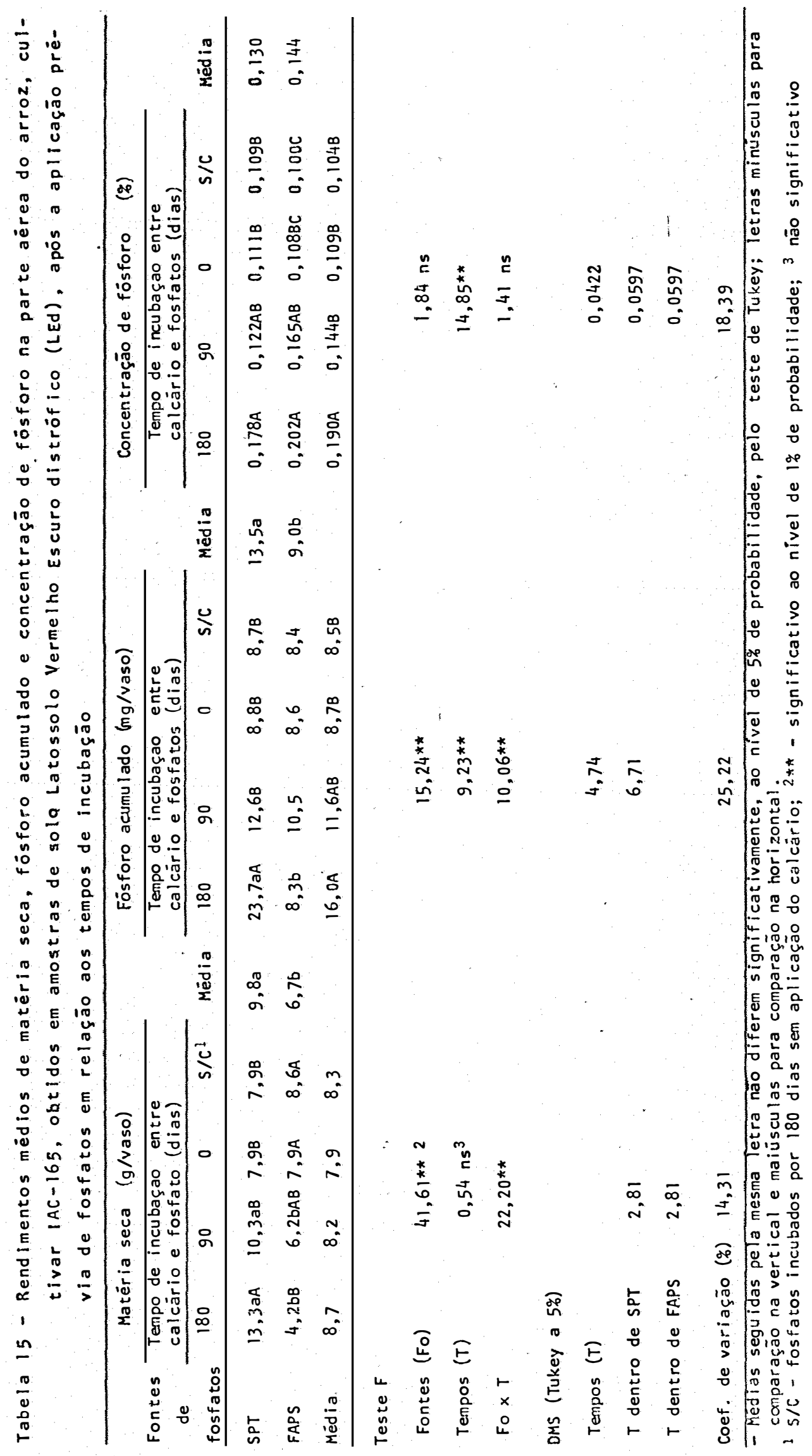


incubação com calcário na presença de SPT, aumentaram o fósforo acumulado na parte aérea, e que os tratamentos sem calcário apresentaram as menores acumulações de fósfo ro, o que está de acordo com a explicação anterior no que se refere ao efeito dos valores de $\mathrm{pH}$ sobre a produção de matéria seca.

Houve também no LEd um efeito significativo dos tempos de incubação sobre a concentração de fósforo em ambas as fontes de fosfatos (Tabela 15), quando se considerou o SPT, observou-se que os tempos de incubação com calcário iaumentaram as concentrações de fósforo na parte aérea e que as menores concentrações foram encontra das no tratamento sem calcārio. Embora o LVd não experi mentou significância, a tendência encontrada foi a mesma (Tabela 14).

Quanto ao comportamento do FAPS nos idife rentes tempos de incubação com calcário, observou-se maio res concentrações de fósforo na parte aérea, na medida que aumentaram os referidos tempos de incubação. As menores concentrações de fösforo foram encontradas nos tratamentos sem calcário (Tabela 15).

0 comportamento das médias apresentadas nas Tabelas 14 e 15, relativas à produção de matéria seca, fós foro acumulado e concentração de fósforo na parte aérea do arroz e considerando-se sobretudo o Superfosfato Triplo (SPT), 
seguiu o verificado na disponibilidade de fósforo medida principalmente através dos extratores: Mehlich, Bray-l e Resina trocadora de ânions (Tabelas 8 e 9). Quando se considerou o Fosfato de Araxá Parcialmente Solubilizado (FAPS), somente o comportamento da produção de matéria se ca, acompanhou a disponibilidade de fósforo medida princi palmente pelos extratores Mehlich e Bray-1.

\subsection{Relação entre teores de fósforo no solo e respos-} ta do arroz

os teores de fósforo "disponivel" obtidos com os quatro extratores estudados antes do plantio, foram correlacionados con à produção de matéria seca e fósforo acumulado na parte aérea do arroz. Utilizou-se uma equação do tipo $Y=a \pm b x$. Pela análise de correlação, encon trou-se uma correlação altamente significativa, entre os teores de fósforo "disponivel" extraidos pelo método Bray 1 e a produção de matēria seca e fósforo acumulado na par te aérea do arroz (Figuras l e 2). O fósforo "disponivel" obtido através do extrator 0lsen + EDTA, também correlacionou com a produção de matéria seca (Figura 3). o baixo coeficiente de correlação obtido em 01 sen, se deve pos sivelmente a que este extrator não mostrou correlação com as formas de fósforo no tratamento com FAPS (Tabela 13); outra causa pode ser a pequena variação nos valores de 


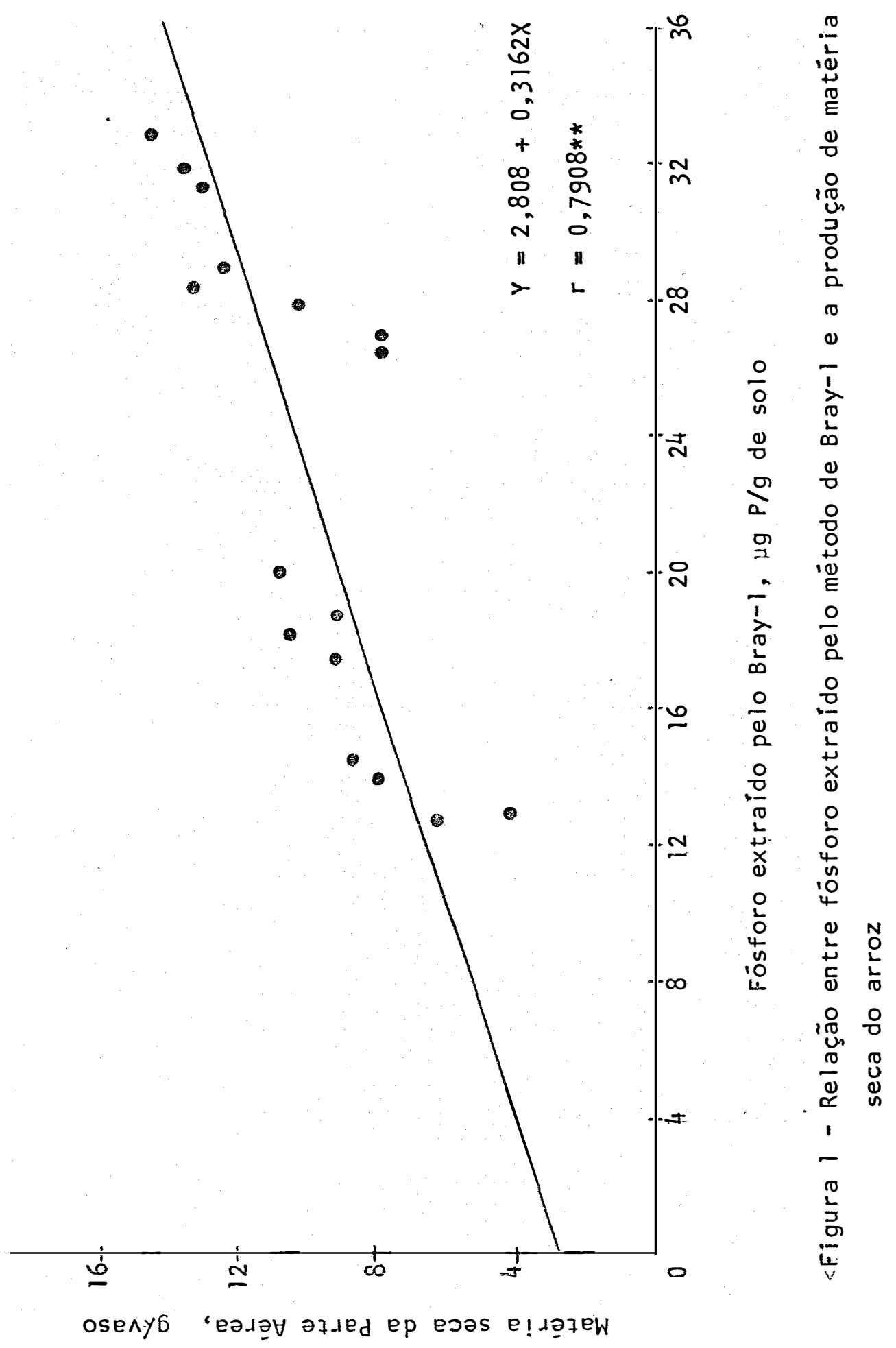




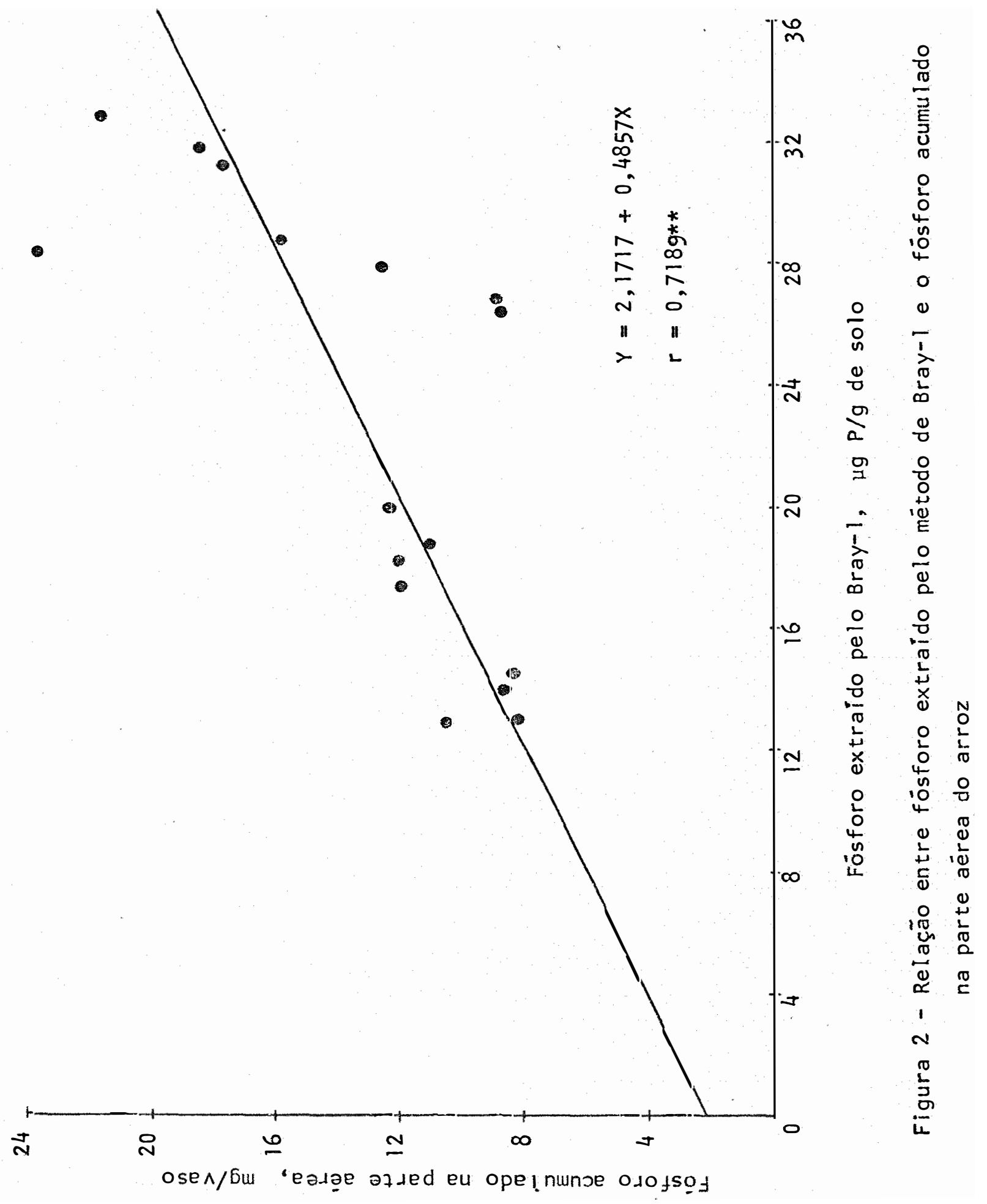




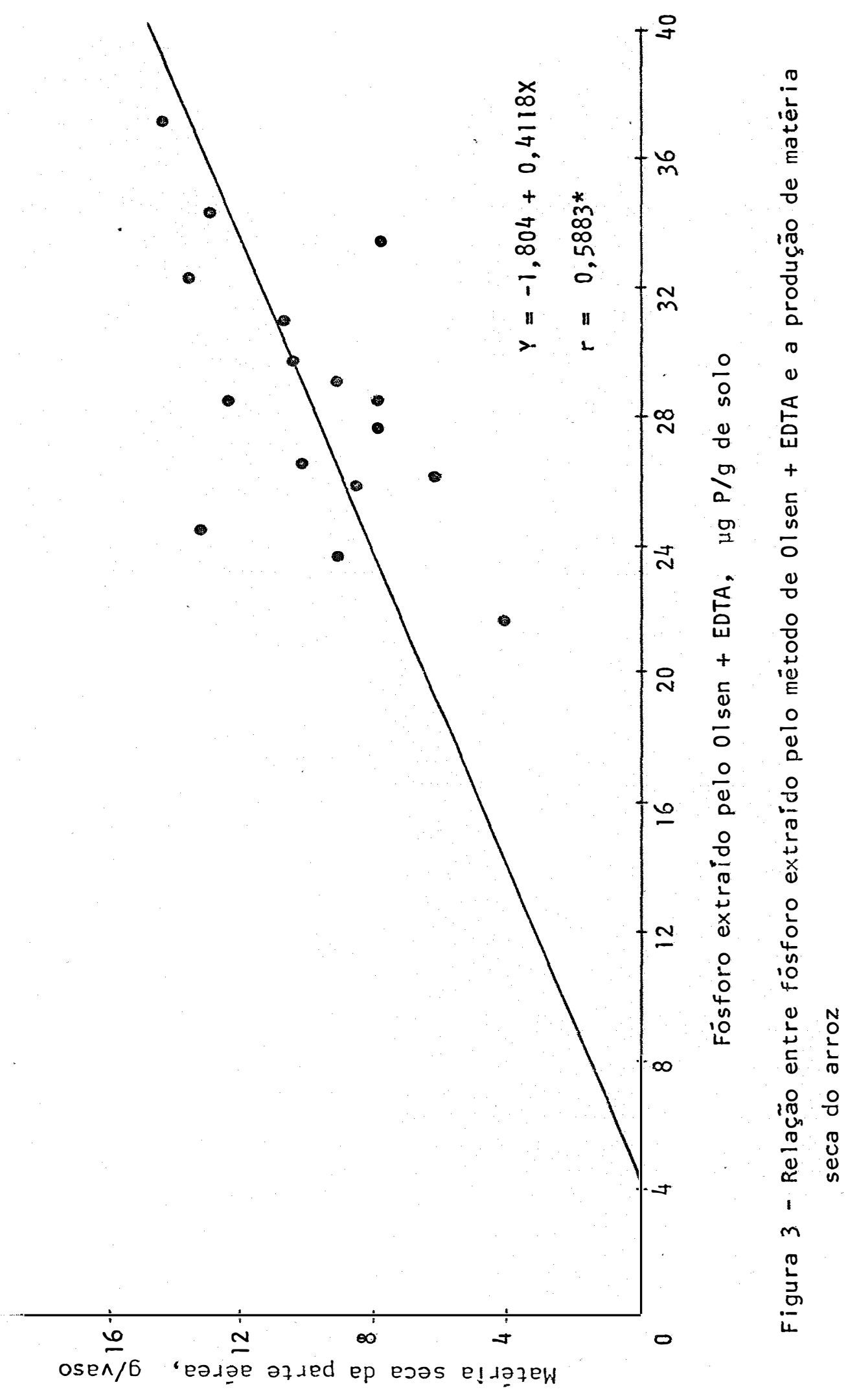


fösforo "disponível" em relação à produção de matēria sea (Figura 3). Tanto o extrator Mehlich como a Resina não correlacionaram com as variáveis da planta, provavelmente, porque o extrator Mehlich extrai fösforo do P-Ca, que é pouco solüvel sob condição de campo. No caso da Resina, o fósforo extraído correlacionou positivamente apenas com P-Al (Tabela 13).

Com o objetivo de verificar o efeito dos teores de fösforo "disponível" sobre a produção de matēria seca e fósforo acumulado na parte aērea (Figuras 1, 2 e 3), foram correlacionados os valores das variāieis da planta com os teores de fósforo "disponivel" extraidos pelos quatro extratores, em amostras de dois solos incubados em diferentes tempos para cada fonte de fösforo sem e com calcā rio (Tabela 16).

Quando os extratores de fósforo do solo foram comparados entre si (Tabela 12), encontrou-se uma correlação positiva e significativa entre Mehlich e Bray-l no SPT; e entre Mehlich e Bray-l e olsen e Bray-l, quando a fonte usada foi o FAPS tanto na presença como na ausência de calcário, tambēm, quando foram correlacionados os teores de fósforo "disponivel" extraidos pelos quatro extratores com as variáveis da planta de arroz (Tabela 16), verificou-se dentro do SPT as melhores correlações para os extratores de Mehlich e Bray-l e para as variäveis pro- 


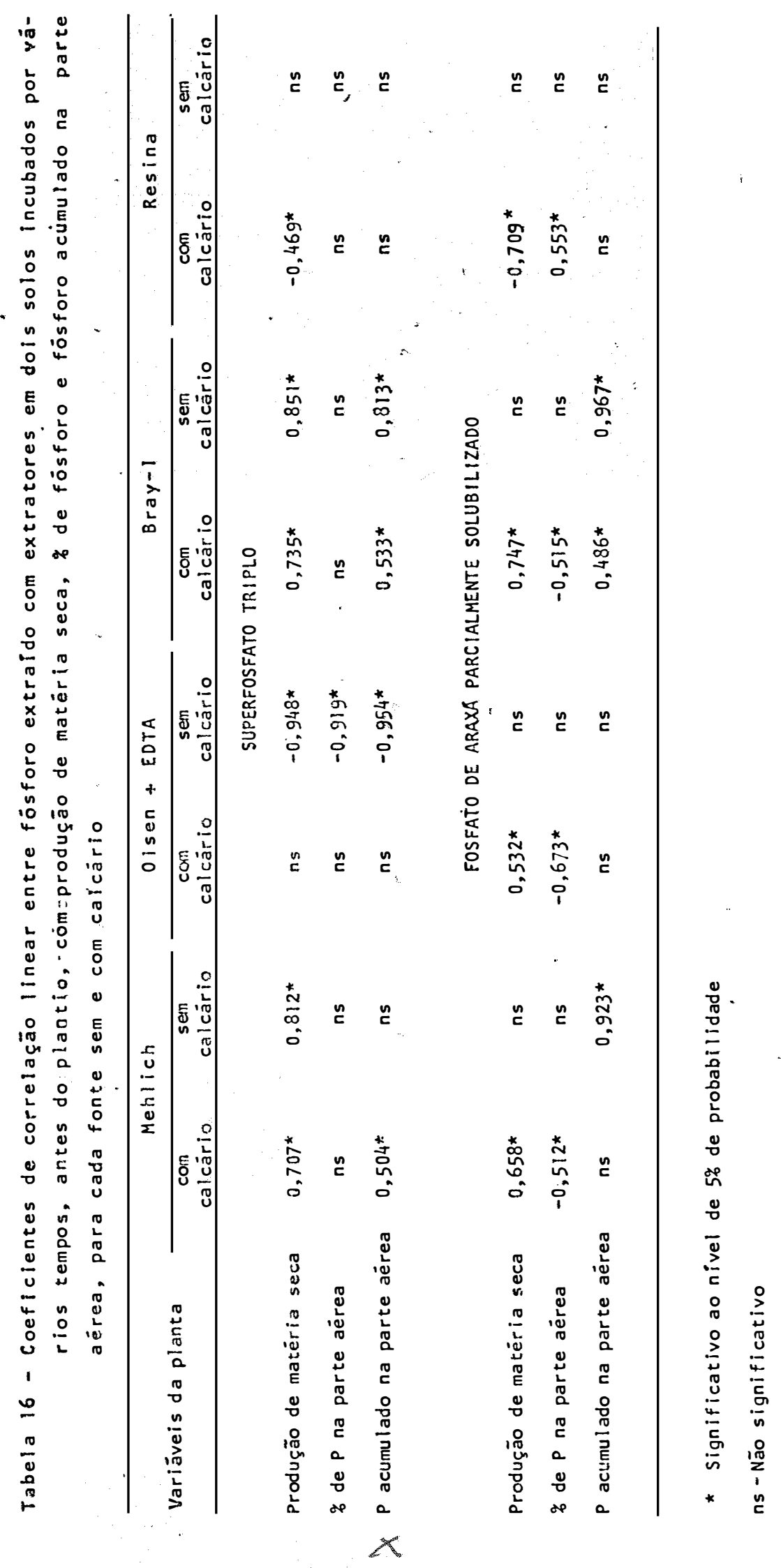




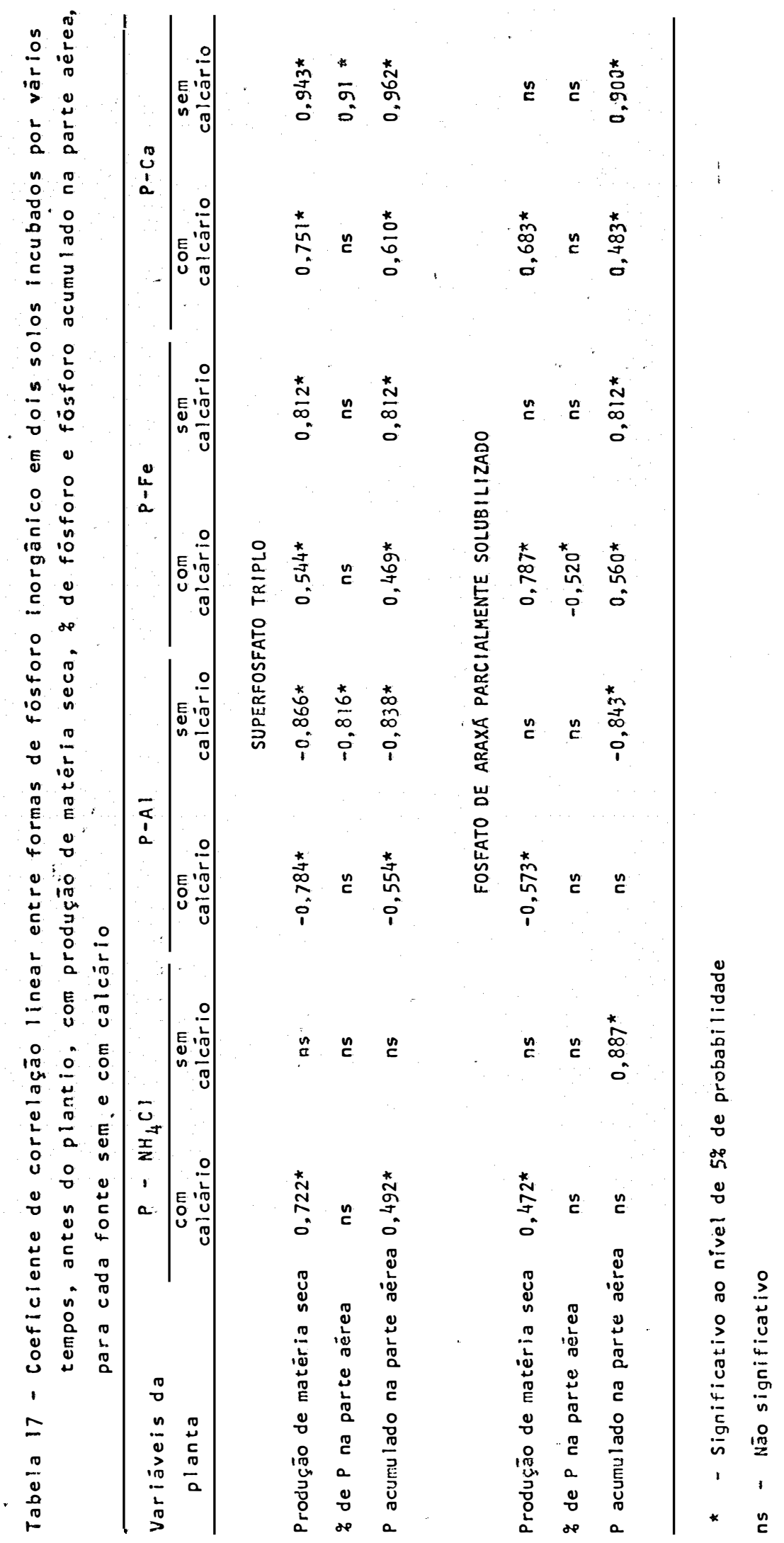


dução de matéria seca e fósforo acumulado na parte aérea do arroz. Já nos tratamentos com fAPS, as melhores correla ções dentro da produção de matēria seca foram obtidas na presença de calcário para Mehlich, 01 sen + EDTA e Bray-l;

o fósforo ácumulado correlacionou positivamente com o extrator Bray-l independentemente da calagem; houve também dentro do FAPS uma correlação entre o extrator Mehlich e o P-acumulado na ausência de cálcário. Não se encontrou correlação positiva dentro do SPT na ausência de calcário, entre o extrator 0lsen + EDTA e as variáveis da planta.

As correlações apresentadas na tabela 16 in dicaram que o melhor paràmetro para avaliar o fósforo "dis ponivel" do solo foi a produção de matéria seca e o fósforo acumulado na parte aérea do arroz. Não se constatou uma correlação positiva entre os teores de fósforo "disponivel" e a porcentagem de fósforo na parte aērea, com exceção da Resina no tratamento com faps com calcário. 0 que está de acordo com os resultados obtidos por PACK e GOMEZ (1956).

os dados relativos às variáveis da planta foram também relacionadas com as frações de fósforo inorgâa nicas e os resultados estão na Tabela 17. Observou-se para o SPT que das frações de fósforo inorgànicas do solo, as de $\mathrm{P}-\mathrm{Ca}, \mathrm{P}-\mathrm{Fe}$ e em menor grau os de $\mathrm{P}-\mathrm{NH}_{4} \mathrm{Cl}$ na presença de calcário, foram os que mais correlacionaram positivamente com a produção de matéria seca e fósforo acumulado na parte aérea. 
Quando se adicionou o FAPS, a produção de matēria seca correlacionou com as frações: $\mathrm{P}-\mathrm{NH}_{4} \mathrm{Cl}, \mathrm{P}-\mathrm{Fe}$ e P-Ca na presença de calcário; entretanto, que o fósforo acumulado correlacionou com as frações P-Fe e P-Ca independente dá calagem e com a fração $\mathrm{P}-\mathrm{NH}_{4} \mathrm{Cl}$ na ausência de calcário. De um modo geral, a fração P-Al não correlacionou positivamente com as variáveis da planta independente mente da fonte de fosfatos adicionada e da presença ou au sência de calcário.

Quando da discussão dos dados da Tabela 13 , encontrou-se que os teores de fósforo "disponivel" extraí dos principalmente pelos extratores Mehlich e Bray-1, cor relacionaram de um modo geral com as frações $\mathrm{P}-\mathrm{NH}_{4} \mathrm{Cl}$, P-Fe e P-Ca independentemente da fonte usada, o que explicaria a absorção preferencial pela planta, do fósforo das formas $\mathrm{P}-\mathrm{Fe}, \mathrm{P}-\mathrm{Ca}$ e $\mathrm{P}-\mathrm{NH}_{4} \mathrm{Cl}$. Ainda deve-se considerar que dentro da quantidade total de fósforo (soma de todas as frações), a maior quantidade de fósforo se encontrava sob a forma de P-Fe e P-Ca, o que justifica a absorção ve rificada neste trabalho. 


\title{
5. CONCLUSOES
}

\author{
Nas condições experimentais deste trabalho \\ e considerando-se os dados obtidos, podem ser tiradas as \\ seguintes conclusões:
}

a - Quando os adubos fosfatados são aplicados em solos sob cerrado 180 dias antes do plantio do arroz, a pro dução de matēria seca da parte aērea aumenta com o tempo de reação do calcário no solo que recebe o SPT e a quantidade de fósforo absorvida pela planta tende a acompanhar a tendência da matéria seca. Com a adição do FAPS a produção de matēria seca tende a dim I nuir na medida que aumenta o tempo de reação entre calcário e adubo, a quantidade de fósforo absorvida, neste caso não acompanha a produção de matéria seca.

b - Com o emprego de SPT em ambos os solos, os teores de fósforo "disponível", extraídos pelos extratores Mehlich, Bray-l e Resina, não variam significativamente 
com os tempos de reação do calcārio e adubo; mas, no caso do extrator 0lsen + EDTA, os teores de P "disponivel" no LVd aumentarão com os tempos de reação do calcário e SPT. Quando se adiciona o FAPS no LVd, os teores de fósforo, extraídos pelos extratores Mehlich e 0lsen + EDTA, tendem a diminuir na medida que aumentam os tempos de reação entre calcārio e FAPS.

Na ausência de calcärio em ambos os solos, os teores de fósforo extraídos por Bray-l e Mehlich tendem a diminuir com o emprego de SPT e aumentar com FAPS, em comparação aos tratamentos com calcārio.

c - Os teores de fósforo "disponivel" determinados pelos extratores Mehlich e Bray-l estão correlacionados positivamente com os de $\mathrm{P}-\mathrm{NH}_{4} \mathrm{Cl}$, $\mathrm{P}-\mathrm{Fe}$ e $\mathrm{P}-\mathrm{Ca}$ e essas relações também acompanham a produção de matéria seca e fósforo acumulado na parte aérea do arroz. 


\section{LITERATURA CITADA}

ALCARDE, J.C. e E. MALAVOLTA, 1982. Solubilidades de um fosfato natural parcialmente acidulado, nos extratores químicos de avaliação do fäsforo em fertilizantes. R. bras. Ci. Solo, Campinas, $6: 59-62$.

ALMEIDA NETO, J.X. de, 1979. Caracterização das formas de fósforo e emprego de diferentes extratores para avaliar o P "disponível" em solos de Goiás. Piracicaba, SP., ESALQ/USP, 138p. (Tese de Doutorado).

AMER, F.; D.R. BOULDIN; C.A. BLACK e F.R. DUKE, 1955. Characterization of soil phosphorus by anion exchange resin adsorption and $\mathrm{p}^{32}$ equilibration. Plant and soil, $\underline{6}(4): 391-408$. 
ASHBY, D.L.; W.E. FENSTER e 0.J. ATTOE, 1966. Effect of partialacidulation and elemental sulfur on availability of phosphorus in Rock Phosphate. Agronomy Journal, 58: $621-625$

BAHIA FILHO, A.F.C. e J.M. BRAGA, 1975. Fósforo em Latossolo do Estado de Minas Gerais: 11. Quantidade de fósfo ro e fösforo "disponivel". Revista Ceres, 22 (119):50-61.

BAHIA FILHO, A.F.C.; C.A. VASCONCELLOS; H.L. SANTOS; J.F. MENDES; G.V.E. PITTA e A.C. OLIVEIRA, 1982. Formas de fósforo inorgânico e fósforo "disponivel" em um Latosso Io Vermelho-Escuro, fertilizado com diferentes fosfatos. R. bras. Ci. Solo, Campinas, 6:99-104.

BARBER, S.A. e A.H. AL-ABBAS, 1964. A soil test for P based upon fractionation of soil phosphorus. I. Correlation of phosphorus fractions with plant available P. Soil Sci. Soc. Am Proc., 28:218-221.

BARBOSA FILHO, M.P.; N.K. FAGERIA e F.M. DALL'ACQUA, 1983. Avaliação agronômica de fontes alternativas de fōsforo em solo de cerrado. EMBRAPA/CNPAF, Sērie: Documentos, $7.12 \mathrm{p}$.

BIASI, J., 1978. Avaliação do fósforo relacionado a diversos extratores químicos em solos de Santa Catarina. ESALQ/ USP, Piracicaba. 181p. (Dissertação de Mestrado). 
BRAGA, J.M., 1969. Comparação de fosfatos aplicados ao fe joeiro. 1. Trabalhos de casa de vegetação. Rev. Ceres, $\underline{16}: 88-101$

BRAGA, J.M. : 1970. Resultados experimentais com o uso de fosfato de Araxá e outras fontes de fósforo. Revisão de Literatura. U.F.V., Viçosa, Sërie Tëcnica, Boletim 21. $61 \mathrm{p}$.

BRAGA, J.M. e B.V. DEFELIPO, 1972a. Relações entre formas de fósforo inorgânico, fósforo disponível e material vegetal em solos sob vegetação de cerrado. I. Trabalhos de laboratório. Rev. Ceres, 19(102):124-136.

BRAGA, J.M. e B.V. DEFELIPO, 1972b. Relação entre formas de fósforo inorgânico, fósforo disponivel e material em solos sob vegetação de cerrado. II. Trabalhos de estufa. Rev. Ceres, 19(104):248-260.

BRAY, R.H. e L.T. KURTZ, 1945. Determination of total organic and available forms of phosphorus in soils. Soil Sci., 59:39-45.

CABALA, R.P. e H.W. FASSBENDER, 1970. Formas del fósforo en suelos de la región cacaotera de Bahia, Brasil. Turrialba; Costa Rica, 20(4):439-444. 
CABALA, R.P. e H.W. FASSBENDER, 1971. Efecto del encalado en las formas y disponibilidad de fósforo en suelos de la región cacaotera. Bahia, Brasil. Turrialba, Costa Rica, $21: 38-46$.

CABALA, R.P., 1979. Reaction de rock phosphate in some Brazilian soils and their utilization by plants. Tese de Doutoramento. Reading, England, University of Reading. $313 p$

CABALA, R.P. e M.B.M. SANTANA, 1983a. Disponibilidade e diagnose de fósforo pela análise química do solo com referência ao Brasil. Rev. bras. Ci. Solo, Campinas, 7:109118.

CATAN I, R.A. e J.R. GALLO, 1955. Avaliação da exigência de calcärio dos solos do Estado de São Paulo mediante a correlação entre o pH e a saturação de bases. Revista. de Agricultura, Piracicaba, 30:49-60.

CHANG, S.C. e M.L. JACKSON, 1957. Fractionation of soil phosphorus. Soil Science, Baltimore, 84(1):133-144.

CHANG, S.C. E M.L. JACKSON, 1958. Soil phosphorus fractions in some representative soils. J. Soil Sci. (9):109-119.

COLEMAN, N.T.; J.T. THORUP E W.A. JACKSON, 1960. Phosphate sorption reactions that involve exchangeable Al. Soil Sci. Baltimore, $90: 1-7$. 
COOKE, I.J.e J. HISLOP, 1963. Use of anions-exchange resin for the assessment of available soil phosphate. Soil sci., Baltimore, $\underline{96}(5): 308-313$.

DELAZARI, P.C.; J.M. BRAGA; R.F. NOVAIS e J.T.L. THIEBAUT, 1980. Disponibilidade de fósforo em solos do Estado de Espirito Santo. ․ bras. Sci. Solo, Campinas, 4:149-153.

EMBRAPA. Empresa Brasileira de Pesquisa Agropecuäria, 1979. Serviço Nacional de Levantamento e Conservação de Solos, Rio de Janeiro, RJ. Manual de Métodos de Análise de Solo, $n \cdot p$.

EMBRAPA. Empresa Brasileira de Pesquisa Agropecuāria, 1981. Centro de Pesquisa Agropecuäria dos Cerrados. Planaltina, DF. Relatörio Técnico Anuàl, 1979-1980. 190p.

FAGERIA, N.K. e M.P. BARBOSA FILHO, 1981. Avaliação de cultivares de arroz para maior absorção de fösforo. pesq. Agropec. Brasil., Brasilia, $16 \underline{6}(6): 777-782$.

FAGERIA, N.K., 1984. Adubação e nutrição mineral da cultura do arroz. Ed. Campus, Rio de Janeiro. $341 \mathrm{p}$.

FASSBENDER, H.W. 1967, Los fosfatos naturaies de Sechura, Peru. Turrialba, 17:159-164. 
FASSBENDER, H.W.; 1. MULLER e F. BALERDI, 1968. Estudio del fósforo en suelos de América Central. I1. Formas y su relación con las plantas. Turrialba, Costa Rica, $18: 333-347$.

FASSBENDER, H.W., 1975. Quimica de suelos. Con énfasis en suelos de América Latina. Editora IICA, Turrialba. $398 p$.

FEITOSA, C.T. e RA!J, Van B., 1976. Influência da natureza de fosfatos aplicados a dois solos no fósforo solúvel em extratores químicos e disponivel para trigo e milho. In: ANAIS DO XV CONGRESSO BRASILEIRO DE CIENCIA DO SOLO, Campinas, p.215-220.

FERREIRA, T.N. e J. KAMINSKI, 1979. Eficiência agronômica dos fosfatos naturais de Patos de Minas e Gafsa puros e modificados por acidulação e calcinação. R. bras. Ci. Solo, Campinas, $\underline{3}: 158-162$.

FREIRE, F.M.; J.M. BRAGA E C.A.S. MARTINS FILHO, 1983. Valor fertilizante de fosfatos solúveis, Araxá e parcialmente acidulado. ㅁ. bras. Ci. Solo, Campinas, 2:65-68.

GOEDERT, W.J.; J.F. PATELLA e J.F.V. MORAIS, 1971. Formas de fósforo num Planossolo do Rio Grande do Sul e sua di $\underline{s}$ ponibilidade para a cultura do arroz irrigado. Pesg. Agropec. bras., Sèr. Agron., 6:39-43. 
GOEDERT, W.J. e E. LOBAT0, 1980. Eficiência agronômica de fosfatos em solos de cerrado. Pesq. Agropec. bras., Brasilia, 15(3):311-318.

HESSE, P.R.; 1971. A textbook to soil chemical analysis. John Murray Ltd., London, 520 .

HISLOP, J. e I.J. COOKE, 1966. Anion exchange resin as a means of assessing soil phosphate status: a laboratory technique. Soil Sci:, Baltimore, 105(1):8-11.

HSU, P.H., 1965. Fixation of phosphate by aluminum and iron in acidic soils. Soil science, Baltimore, $99(6): 398-$ 402 .

JORGE, J.A. e J. VALADARES, 1969. Formas de fósforo em solos do Estado de São Paulo. Bragantia, Campinas, 28(2):23-30.

JORGE, J.A., 1983. Solo: manejo e adubação. Editora Nobel S.A., São Paulo, 315p. (2a. edição).

KHANNA, P.K., 1967. Inorganic soil phosphate fractions as related to soil test values by common method. Plant and Soil, 26:277-284.

KORNDORFER, G.H., 1978. Capacidade de fosfatos naturais e artificiais fornecerem fósforo para as plantas de trigo. Teses E Monografias, n: 7, Porto Alegre,. $61 \mathrm{p}$. 
LARSEN, S., 1967. Soil phosphorus. Advance in Agronomy, 19: $151-209$.

LEHER, J.R. e G.H. MCCLELLAN, 1972. A revised laboratory reactivity scale for evaluating phosphate rock for direct application. Muscle Schools, Alabama, National Fertilizer Development Center. 36p. (Bulletin $Y-43$ ).

LINDSAY, W.L.; A.W. FRAZIER E H.F. STEPHESON, 1962.

Identification of reaction products from phosphate fertilizers in soils. Soil Sci. Soc. Amer. Proc., 26:446-452.

LOPES, A.S., 1977a. Fertilidade do Solo. Anotações de aula. Lavras, ESAL, mimeografado. $272 \mathrm{p}$.

LOPES, A.S., 1977b. Available water, phosphorus fixation and zinc levels in Brazilian soils in relation to their physical, chemical and mineralogical properties. Dep. of Soil Science, NCSU, Raleigh. 189p. (Tese de Pho).

LUTZ Jr., J.A., 1971. Comparison of partially acidulated rock phosphate and concentraded superphosphate as sources of phosphorus for corn. Agronomy Journal, 63:919-922.

MALAvolta, E., 1976. Manual de quimica agricola. Nutrição de plantas e fertilidade do salo. Editora Agronómica Ceres, São Paulo. 528 . 
MALAVOLTA, E.; G.C. VITTI; J.C. ALCARDE; C.A. ROSOLEM O D. FORNASIERI FILHO, 1981. Aproveitamento de um fosfato natural parcialmente solubilizado pelas culturas do arroz, milho e soja. 1. Resultados preliminares. Anais da

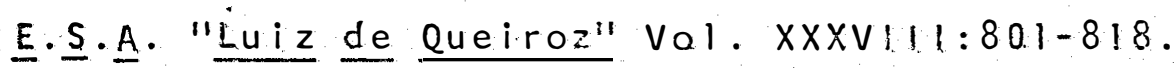

MALAVOLTA, E.; C.A. PEIXE; F.P. RUIVO; J.G. CARVALHO; P.G. GUIMARÃES e G.C. VITTI, 1982. Aproveitamento de um fosfata natural parcialmente solubilizado pela cultura da

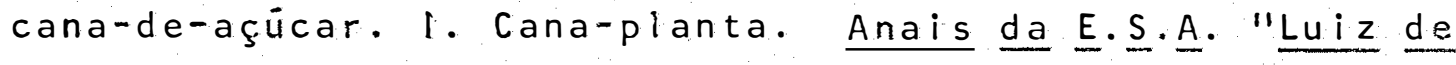
Queiroz", vol. XXX1x:563-577.

MENGEL, K. e E. A. KIRKBY, 1979. Principles of plant nutrition. International Potash Institute Berne, Switzerland. 593 p.

MTYAKE, M.; M- ISMUNADJ1; I. ZULKARNAINI E S. ROECHAN, 1984. Phosphate response of rice in Indonesian paddy fields. TROPICAL AGRICULTURE RESEARCH CENTER, Technical Bulletin nํ. 17, Japan, $78 p$.

NAKAYAMA, L.H.1., 1982. Estudos agrícolas sobre o aproveita mento do fosfato de Araxá parciaimente solubilizado. ESALQUSP, Piracicaba, SP. 97p. (Dissertação de Mestrado).

NOVAES, N.J.; L.E. GUTIERREZ; G.C. VITTI e D.A. BANZATO, 1983. Efeito de fontes e doses de fósforo na cultura do capim gamba (Andropogon gayanos Kunth, variedade Bisquamulatum). Trabalho apresentado no $x \perp x$ Congresso Brasileiro de Ciência do Solo, Curitiba, PR. 
NOVELINO, 3.O.; R.F. NOVAIS; J.C.L. NEVES; L.M. COSTA E N.F. BARROS, 1985. Solubilização de fosfato-de-Araxá, em diferentes tempos de incubação, com amostras de cinco latos solos, na presença e na ausência de calagem. R. bras. Ci. Solo, $2: 13-22$.

PACK, M.R. e R.S. GOMEZ, 1956. Correlation between plant analysis and soil test in New Mexico. Soil Sci. Soc. Amer. Proc., 20:529-531.

PALMA, G. e H.W. FASSBENDER, 1970. Estudio del fósforo en suelos de Améríca Central. V. Uso de resinas de intercambio para evaluar la disponibilidade de P. Turrialba, Costa Rica, 20:279-287.

PARFITT, R.L.; R.J. ATKINSON E R.S.C. SMART, 1975. The mechanism of phosphate fixation by iron oxides. Soll Sci. Soc. Amer. Proc., 39:837-841.

PEREIRA, J.R. e C.M.B. FARIA, 1978. Disponibilidade de fósforo aplicado em um vertissolo do médio são francisco, avaliada por métodos químicos. ․ pras. Ci. Solo, Campinas, $2: 125-128$.

PRATT, P.F. e GARBER, M.J., 1964. Correlations of phosphorus availability by chemical tests with inorganic phosphorus fractions. Soil Sai. Soc. Proc., 28:23-26. 
RAlJ, B. van, 1978. Seleção de métodos de laboratōrio para avaliar a disponibilidade de fösforo em solos. R. bras. Ci. Solo, Campinas, 2:1-2.

RAIJ, B. van e A. Van DIEST, 1980. Phosphate supplying power or rock phosphate in an oxisol. Plant and Soll, 55:97-104.

RAIJ, B. van; C.T. FElTOSA e Q.A.C. CARMELLO, 1982. A adubação fosfatada no Estado de sãofaulo. In: OLIVEIRA, A.J.; S. LOURENÇO e W.J. GOEDERT, Eds. Adubação fosfatada no Brasil. Brasilia, EMBRAPA/DID, p.103-136.

RAlJ, B.van: e J.A. QUAGGI0, 1983. Mëtodos de anälises do solo para fins de fertilidade. Campinas, Instituto Agronómico de Campinas. Boletim Técnico n: 81. 3lp.

SARRUGE, J.R. e H.P. HAAG, 1974. Análise química de plantas. ESALQ/USP. Departamento de Química. $56 \mathrm{p}$.

SFREDO, G.J.; C.M. BORKERT; D.S. CORDEIRO; J.B. PALHANO E R.C. DITTRICH, 1979. Comparaçao de cinco extratores de fösforo do solo, considerando-se o tempo de incorparação de três adubos fosfatados. R. bras. Ci. solo, 3:111-115. SHINDE, R.N.; P.A. SARANGAMATH e S. PATNAIR, 1978. Efficiency of $\mathrm{HCl}$ and $\mathrm{H}_{2} \mathrm{SO}_{4}$ acidulated rock phosphates for rice (oryza sativa L.) on acid sois. Plant and soil, 50:575-584. SMYTH, F.J. e P.A. SANCHEZ, 1980. Niveis criticos de fósforo para arroz de sequeiro em um Latossolo dos cerrados. R. bras. Ci. Solo, Campinas, $4: 88-92$. 
SOIL SURVEY STAFF, 1975. Soll taxonomy. Agric. Handbook no 436, USDA - U.S. Government Printing office, Washington, D.C.

TANAKA, R.T.; V.G. BAHIA; A.M. COELHO E J.C. FREIRE, 1981. Seleção de extratores de fósforo do solo em função das respostas das plantas de milho (Zea mays L.) e da adubação com fosfato Patos-de-Minas em condições de casa de vegetação. R. bras. Ci. Solo, Campinas, 5:38-42.

VETORRI; L. 1969. Métodos de anālise de solo. Equipe de Pedologia e Fertilidade de Solo (Brasil). Bol. Tec. 7. Rio de Janeiro.

VOLKMEISS, S.J. e B. Van RAIJ, 1976. Retençäo e disponibilidade de fósforo em solos. IV simpósio sobre o cerrado Base para utilização agropecuária. Brasilia, DF., 317-332. 